\title{
Atmospheric aerosol compositions and sources at two national background sites in northern and southern China
}

\author{
Qiao Zhu ${ }^{1}$, Ling-Yan He ${ }^{1}$, Xiao-Feng Huang ${ }^{1}$, Li-Ming Cao ${ }^{1}$, Zhao-Heng Gong ${ }^{1, a}$, Chuan Wang ${ }^{1}$, Xin Zhuang $^{1}$, and \\ Min $\mathrm{Hu}^{2}$ \\ ${ }^{1}$ Key Laboratory for Urban Habitat Environmental Science and Technology, School of Environment and Energy, Peking \\ University Shenzhen Graduate School, Shenzhen, 518055, China \\ ${ }^{2}$ State Key Joint Laboratory of Environmental Simulation and Pollution Control, College of Environmental Sciences and \\ Engineering, Peking University, Beijing, 100871, China \\ anow at: John A. Paulson School of Engineering and Applied Sciences, Harvard University, Cambridge, Massachusetts, USA \\ Correspondence to: Xiao-Feng Huang (huangxf@pku.edu.cn)
}

Received: 28 March 2016 - Published in Atmos. Chem. Phys. Discuss.: 29 April 2016

Revised: 15 July 2016 - Accepted: 15 July 2016 - Published: 15 August 2016

\begin{abstract}
Although China's severe air pollution has become a focus in the field of atmospheric chemistry and the mechanisms of urban air pollution there have been researched extensively, few field sampling campaigns have been conducted at remote background sites in China, where air pollution characteristics on a larger scale are highlighted. In this study, an Aerodyne high-resolution time-of-flight aerosol mass spectrometer (HR-ToF-AMS), together with an Aethalometer, was deployed at two of China's national background sites in northern (Lake Hongze site; $33.23^{\circ} \mathrm{N}, 118.33^{\circ} \mathrm{E}$; altitude $21 \mathrm{~m}$ ) and southern (Mount Wuzhi site; $18.84^{\circ} \mathrm{N}, 109.49^{\circ} \mathrm{E}$; altitude $958 \mathrm{~m}$ ) China in the spring seasons in 2011 and 2015 , respectively, in order to characterize submicron aerosol composition and sources. The campaign-average $\mathrm{PM}_{1}$ concentration was $36.8 \pm 19.8 \mu \mathrm{g} \mathrm{m}^{-3}$ at the northern China background $(\mathrm{NCB})$ site, which was far higher than that at the southern China background (SCB) site $\left(10.9 \pm 7.8 \mu \mathrm{g} \mathrm{m}^{-3}\right)$. Organic aerosol (OA) $(27.2 \%)$, nitrate $(26.7 \%)$, and sulfate $(22.0 \%)$ contributed the most to the $\mathrm{PM}_{1}$ mass at $\mathrm{NCB}$, while OA $(43.5 \%)$ and sulfate $(30.5 \%)$ were the most abundant components of the $\mathrm{PM}_{1}$ mass at $\mathrm{SCB}$, where nitrate only constituted a small fraction $(4.7 \%)$ and might have contained a significant amount of organic nitrates (5-11\%). The aerosol size distributions and organic aerosol elemental compositions all indicated very aged aerosol particles at both sites. The OA at SCB was more oxidized with a higher average oxygen to carbon $(\mathrm{O} / \mathrm{C})$ ratio $(0.98)$ than that NCB (0.67). Positive matrix factorization (PMF) analysis
\end{abstract}

was used to classify OA into three components, including a hydrocarbon-like component (HOA, attributed to fossil fuel combustion) and two oxygenated components (OOA1 and OOA2, attributed to secondary organic aerosols from different source areas) at NCB. PMF analysis at SCB identified a semi-volatile oxygenated component (SV-OOA) and a lowvolatility oxygenated component (LV-OOA), both of which were found to be secondary species and could be formed from precursors co-emitted with BC. Using the total potential source contribution function model, the likely source areas of the major $\mathrm{PM}_{1}$ components at both sites were a on large regional scale in East Asia. The possible sources may include not only emissions from the Chinese mainland but also emissions from ocean-going cargo ships and biomass burning in neighboring countries.

\section{Introduction}

With the rapid economic growth and urbanization, severe events of poor air quality, characterized by high concentrations of fine particles $\left(\mathrm{PM}_{2.5}\right)$, have frequently occurred in China. Average $\mathrm{PM}_{2.5}$ concentrations across China have been documented, with high levels appearing in northern regions and relatively low levels in southern areas (van Donkelaar et al., 2010; Yang et al., 2011). Many measurements and source analyses of ambient aerosols were conducted in different areas of China, giving local aerosol composition and 
sources. For example, Huang et al. (2014) found that, during a single winter pollution event, the levels, compositions, and sources of $\mathrm{PM}_{2.5}$ are significantly different for four cities in China. The summary of $\mathrm{PM}_{2.5}$ measurement based on offline filter sampling across China by Yang et al. (2011) also revealed largely variable compositions for different areas. Since 2006, meaningful clues regarding the interpretation of the compositions, sources, and the evolution processes have been gleaned through field campaigns with professional online tools. For example, Aerodyne aerosol mass spectrometer (AMS) instruments are capable of online measuring chemical composition of non-refractory submicron aerosol species (Canagaratna et al., 2007; Ng et al., 2011b). These previous campaigns mostly focused on much polluted areas in eastern China, such as the Beijing-Tianjin-Hebei area (Takegawa et al., 2009; Huang et al., 2010; Sun et al., 2010, 2012, 2013, 2015; Zhang et al., 2011; Hu et al., 2013), the Yangtze River Delta (Huang et al., 2012, 2013), and the Pearl River Delta (He et al.,2011; Xiao et al., 2011; Lee et al., 2013), Xu et al. (2014) also reported AMS measurement results in a western city of Lanzhou in China. In addition, Wang et al. (2016) recently used an Aerodyne soot particle aerosol mass spectrometer (SP-AMS), for the first time in China, to investigate the occurrence of fullerene soot in ambient air. According to these studies, organic aerosol (OA) was commonly found to be the primary aerosol component, accounting for more than $30 \%$ of the total measured particle mass (e.g., Takegawa et al., 2009; Huang et al., 2010, 2011, 2012; Sun et al., 2015). Furthermore, positive matrix factorization (PMF) analysis based on the OA mass spectra was used to separate OA into several factors that indicate different aerosol sources. Specifically, a hydrocarbon-like OA (HOA) factor, attributed to primary emissions associated with oil combustion, and an oxygenated OA (OOA) factor, attributed to photochemically formed secondary organic matter, were most frequently distinguished and quantified, while cooking OA, biomass burning OA, and coal burning OA were also identified in some field campaigns (e.g., Huang et al., 2010, 2011, 2012; He et al., 2011; Hu et al., 2013). Recently, a novel PMF procedure, using the multi-linear engine (ME-2), was developed to apportion the OA sources in Beijing and Xi' an of China, allowing for a better selection of the source apportionment solution (Elser et al., 2016). However, nearly all previous AMS studies in China have focused on sources and chemical properties of aerosol particles in the very polluted urban or urban downwind areas with strong local source emissions, and thus these results cannot well reflect the general air pollution characteristics on a larger regional scale. The regional air pollution has been found to not only determine air quality in rural or remote areas but also be a critical factor in determining urban air quality in China, such as in Beijing, Shanghai, and Shenzhen (Huang et al., 2010, 2012; He et al., 2011).

So far, several measurements and source analyses based on AMS have been conducted at background sites around the world. Sun et al. (2009) reported the composition and size distribution of NR-PM 1 at the Whistler Peak in Canada. Chen et al. $(2009,2015)$ conducted an AMS study to characterize submicron biogenic organic particles in the Amazon Basin. Ovadnevaite et al. (2011) demonstrated the occurrence of primary marine organic aerosol plumes on the west coast of Ireland. Du et al. (2015) described the aerosol composition using an Aerosol Chemical Speciation Monitor (ACSM) at a national background monitoring station in the Tibetan Plateau in western China. These background site aerosol studies were all conducted in remote areas, which represent global background atmosphere rather than regional background atmosphere. However, regional background atmosphere is more critical to reflect the general picture of anthropogenic emissions in hot polluted regions. In this study, we performed online aerosol measurement field campaigns at two national air background sites in both the northern and southern region in eastern China, which has a population of more than 1 billion and is characterized by high air pollution levels, as a result of high urbanization and industrialization. An Aerodyne high-resolution time-of-flight aerosol mass spectrometer (HR-ToF-AMS), together with an Aethalometer, was deployed at the two background sites to characterize and compare submicron aerosol compositions and evolution processes. The AMS datasets were then further analyzed based on the PMF method and the total potential source contribution function (TPSCF) model to gain more insights into particle source categories and origins in eastern China.

\section{Experimental methods}

\subsection{Sampling sites and meteorological conditions}

The data presented in this study were collected at the Lake Hongze site from March to April in 2011 and at the Mount Wuzhi site from March to April in 2015. The Lake Hongze site $\left(33.23^{\circ} \mathrm{N}, 118.33^{\circ} \mathrm{E}\right.$; altitude $\left.21 \mathrm{~m}\right)$ is located at the center of a wetland natural reserve in Jiangsu Province in northern China. Jiangsu, as one of the most affluent areas of China, has a dense population and is highly industrialized. The Mount Wuzhi site $\left(18.84^{\circ} \mathrm{N}, 109.49^{\circ} \mathrm{E}\right.$; altitude $958 \mathrm{~m}$ ) is located on the highest peak of a mountain in Hainan Province in southern China. Hainan is separated from the mainland China by a narrow strait and is famous for tourism due to its beautiful natural scenery. Figure 1 shows the locations of both sites. These two sampling sites are relatively far from urban and industrial areas, serving as official national air quality background sites of China. Springtime was chosen as the intensive observation period because the wind in this season is the most variable in the whole year, and thus more representative particles for each site could be collected. Although the sampling years were different for the two sites, the year-to-year difference of air pollution at one site was far smaller than the difference between northern China and 


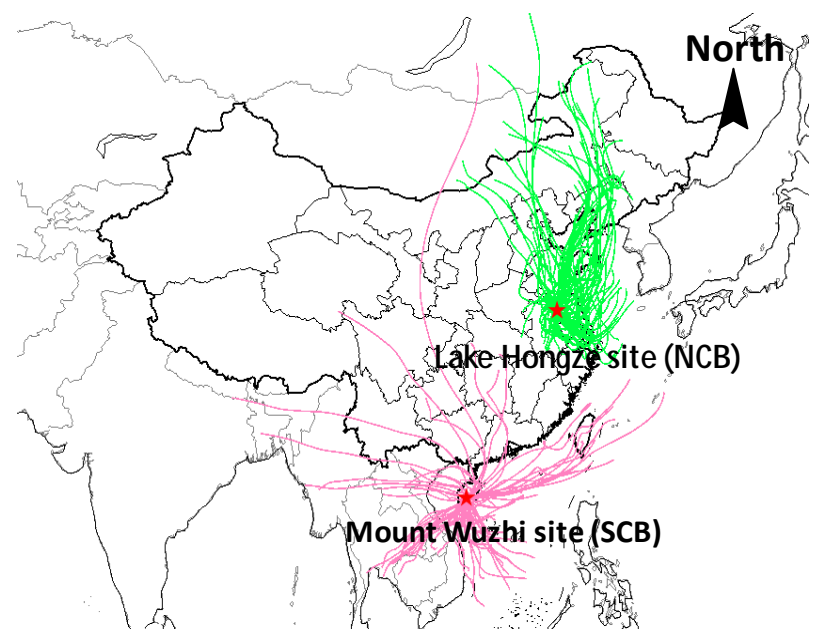

Figure 1. Locations of the Lake Hongze site (NCB) and Mount Wuzhi site (SCB). The green and pink lines represent the typical $48 \mathrm{~h}$ near-ground ( $100 \mathrm{~m}$ above ground level) air mass backtrajectories during the sampling campaigns.

southern China. According to the official monitoring data (http://www.jshb.gov.cn/), the annual average $\mathrm{PM}_{2.5}$ mass concentration in Jiangsu Province was 73 for 2013, 66 for 2014, and $57 \mu \mathrm{g} \mathrm{m}^{-3}$ for 2015 , while that in Hainan Province was only 26 for 2013, 28 for 2014, and $20 \mu \mathrm{g} \mathrm{m}^{-3}$ for 2015 (http://www.ep.hainan.gov.cn/). In addition, the high altitude of the Mount Wuzhi site would also not make a big difference for air pollution from the ground site in Hainan Province due to its weak anthropogenic emissions. During the sampling period in 2015, the average $\mathrm{PM}_{2.5}$ mass concentration at the Mount Wuzhi site was $15 \mu \mathrm{g} \mathrm{m}^{-3}$ and that at another ground site at the foot of the mountain, about $60 \mathrm{~km}$ to the south, was quite similar $\left(16 \mu \mathrm{g} \mathrm{m}^{-3}\right)$. The meteorological data obtained during the two campaigns are summarized in Table 1, and the corresponding near-ground air mass back-trajectories are plotted in Fig. 1.

\subsection{HR-ToF-AMS operation}

As the details regarding the instrumental setup and data processing at the northern China background (NCB) were the same as those at the southern China background (SCB), we focus on SCB in this part. The HR-ToF-AMS (Aerodyne) was deployed in an air-conditioned room with the temperature maintained at about $24^{\circ} \mathrm{C}$ at SCB to measure particulate matter, typically referred to as non-refractory $\mathrm{PM}_{1}$ (Canagaratna et al., 2007). A $\mathrm{PM}_{2.5}$ cyclone inlet was set up on the roof of the building to remove coarse particles and introduce the air stream into the room through a copper tube with a flow rate of $10 \mathrm{~L} \mathrm{~min}^{-1}$. The HR-ToF-AMS sampled isokinetically from the center of the copper tube at a flow rate of $80 \mathrm{~mL} \mathrm{~min}^{-1}$. In addition, a Nafion dryer was positioned upstream of the HR-ToF-AMS to eliminate the po-
Table 1. Meteorological conditions and $\mathrm{PM}_{1}$ species concentrations during NCB and SCB campaigns.

\begin{tabular}{llll}
\hline \multicolumn{2}{c}{ Sampling site } & NCB & SCB \\
\hline \multicolumn{2}{c}{ Sampling period } & 19 Mar to 24 Apr, 2011 & 18 Mar to 15 Apr 2015 \\
\hline Meteorology & $T\left({ }^{\circ} \mathrm{C}\right)$ & $13.2 \pm 5.0$ & $22.6 \pm 3.6$ \\
& $\mathrm{RH}(\%)$ & $56.9 \pm 10.6$ & $87.4 \pm 16.3$ \\
& $\mathrm{WS}\left(\mathrm{m} \mathrm{s}^{-1}\right)$ & $4.0 \pm 2.6$ & $3.6 \pm 2.5$ \\
\hline Species $\left(\mu \mathrm{g} \mathrm{m}^{-3}\right)$ & $\mathrm{Org}$ & $9.8 \pm 5.6$ & $4.9 \pm 3.6$ \\
& $\mathrm{SO}_{4}^{2-}$ & $7.7 \pm 5.0$ & $3.4 \pm 2.8$ \\
& $\mathrm{NO}_{3}^{-}$ & $9.4 \pm 6.7$ & $0.5 \pm 0.6$ \\
& $\mathrm{NH}_{4}^{+}$ & $5.5 \pm 3.2$ & $1.5 \pm 1.1$ \\
& $\mathrm{Chl}$ & $0.3 \pm 0.3$ & $0.03 \pm 0.03$ \\
$\mathrm{BC}^{2}$ & $2.6 \pm 1.7$ & $0.7 \pm 0.5$ \\
& $\mathrm{PM}_{1}$ & $36.8 \pm 19.8$ & $10.9 \pm 7.8$ \\
\hline
\end{tabular}

tential influence of relative humidity on particle collection (Matthew et al., 2008). A more detailed technical description of the HR-ToF-AMS can be found in the literature (DeCarlo et al., 2006; Canagaratna et al., 2007). The HR-ToFAMS was calibrated for inlet flow, particle sizing, and ionization efficiency (IE) at the beginning and end of the campaign by following the standard protocols (Drewnick et al., 2005; Jayne et al., 2000). The IE and size calibration were performed with size-selected pure ammonium nitrate particles. The instrument was operated in two ion optical modes in a cycle of $4 \mathrm{~min}$, including $2 \mathrm{~min}$ for the $\mathrm{V}$ mode, to obtain the mass concentrations of the non-refractory species, in which there was $100 \mathrm{~s}$ for the particle time-of-flight (PToF) mode to determine the size distributions of the species, and 2 min for the $\mathrm{W}$ mode to obtain high-resolution mass spectral data. An Aethalometer (AE-31, Magee) was used for simultaneous measurement of refractory black carbon (BC) with a time resolution of $5 \mathrm{~min}$ for a better closure of fine particles in the campaign.

\subsection{HR-ToF-AMS data processing}

The HR-ToF-AMS data analysis was performed using the standard AMS data analysis software packages (SQUIRREL version 1.57 and PIKA version 1.16, downloaded from the ToF-AMS software downloads webpage) in Igor Pro 6.37 (Wave Metrics Inc.). The composition-dependent collection efficiency (CE) was applied to the data based on the method in Middlebrook et al. (2012), and the obtained CE values were mostly around 0.5. Organic elemental analysis was carried out using the latest procedures (Canagaratna et al., 2015), which improved the estimation method from that of Aiken et al. (2008).

PMF analysis has been widely applied in AMS data processing for organic aerosol source apportionment (Zhang et al., 2010; Ng et al., 2010; Huang et al., 2010, 2013). In this study, PMF analysis was performed on the high-resolution organic mass spectra $(m / z, 12-150)$ obtained from HR-ToFAMS data. The organic data matrix and error matrix input into the PMF analysis (Ulbrich et al., 2009) were generated with the default fragmentation waves in PIKA version 1.16. 
Before running the PMF, ions with a signal-to-noise ratio less than 0.2 were removed and ions with a signal-to-noise ratio ranging between 0.2 and 2 were downweighted by a factor of 2. The ions of $\mathrm{H}_{2} \mathrm{O}^{+}, \mathrm{HO}^{+}, \mathrm{O}^{+}$, and $\mathrm{CO}^{+}$were removed from the data and error matrices since they were determined according to their relationship with $\mathrm{CO}_{2}^{+}$, and thus including them in the PMF analysis could introduce additional weight to $\mathrm{CO}_{2}^{+}$(Ulbrich et al., 2009). The obtained PMF solutions were evaluated based on the procedure outlined in Zhang et al. (2011). The optimal solutions at both sites were examined for their residuals of PMF fits, MS signatures, their correlation with tracers, diurnal variations, and other characteristics. The diagnostic plots of the chosen results at the two sites are shown in Figs. S1 and S2 in the Supplement. The results show that PMF solutions with factor number greater than 3 at NCB and two at SCB provided no new distinct factors and instead displayed splitting behavior of the existing factors. The $Q / Q_{\text {expected }}$ and the factors obtained for different FPEAK (from -1.0 to 1.0) and SEED (from 0 to 250) values made a small difference in the OA components produced. An FPEAK value of 0 was finally used for both sites because of the lowest $Q / Q_{\text {expected }}$ and that the use of FPEAK values different from 0 did not improve the correlations between PMF factors and external tracers. Based on all tests in the PMF analysis, the three factors at $\mathrm{NCB}$ were assigned as HOA, OOA1, and OOA2, and the two factors at SCB were identified as semi-volatile OOA (SV-OOA) and lowvolatility OOA (LV-OOA), as further discussed in Sect. 3.5. More cases of the PMF analysis can be found in our previous publications (Huang et al., 2010, 2012; He et al., 2011).

\subsection{Estimation of organic nitrates}

Note that the nitrate measured by the HR-ToF-AMS is the nitrate functionality $\left(-\mathrm{ONO}_{2}\right)$, which may include inorganic and organic nitrates. Farmer et al. (2010) reported an approach to quantify organic nitrates with the HR-ToF-AMS data. The nitrate portion of inorganic and organic nitrates primarily fragments to $\mathrm{NO}^{+}$and $\mathrm{NO}_{2}^{+}$ions. Previous laboratory studies have shown that $\mathrm{NO}^{+} / \mathrm{NO}_{2}^{+}\left(\mathrm{NO}_{x}^{+}\right.$ratio $)$is different for organic nitrate and $\mathrm{NH}_{4} \mathrm{NO}_{3}$, and several groups have reported that the $\mathrm{NO}_{x}^{+}$ratios observed in the AMS spectra for organic nitrates are typically 2-3 times higher than those for $\mathrm{NH}_{4} \mathrm{NO}_{3}$ (Fry et al., 2009; Bruns et al., 2010; Farmer et al., 2010; Boyed et al., 2015). Due to the very different average $\mathrm{NO}_{x}^{+}$ratios $\left(R_{\mathrm{NH}_{4} \mathrm{NO}_{3}}\right.$ and $\left.R_{\mathrm{ON}}\right)$, the $\mathrm{NO}_{2}$ and $\mathrm{NO}$ concentrations for $\mathrm{ON}\left(\mathrm{NO}_{2}\right.$, ON and $\left.\mathrm{NO}_{\mathrm{ON}}\right)$ can be estimated by Eqs. (1) and (2):

$\mathrm{NO}_{2, \mathrm{ON}}=\frac{\mathrm{NO}_{2, \mathrm{obs}} \times\left(R_{\mathrm{obs}}-R_{\mathrm{NH}_{4} \mathrm{NO}_{3}}\right)}{R_{\mathrm{ON}}-R_{\mathrm{NH}_{4} \mathrm{NO}_{3}}}$,

$\mathrm{NO}_{\mathrm{ON}}=R_{\mathrm{ON}} \times \mathrm{NO}_{2, \mathrm{ON}}$,

where $R_{\text {obs }}$ is the ambient $\mathrm{NO}_{x}^{+}$ratio. For each dataset, $R_{\mathrm{NH}_{4} \mathrm{NO}_{3}}$ is determined by IE calibration using pure
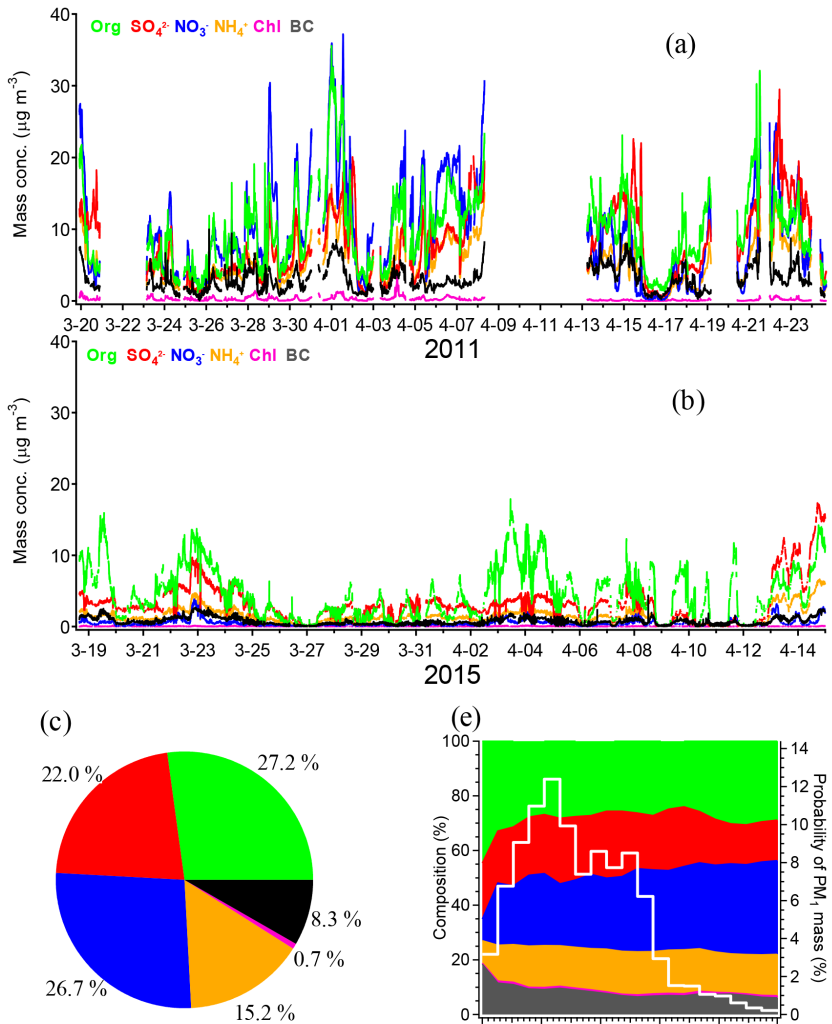

(e)

(d)
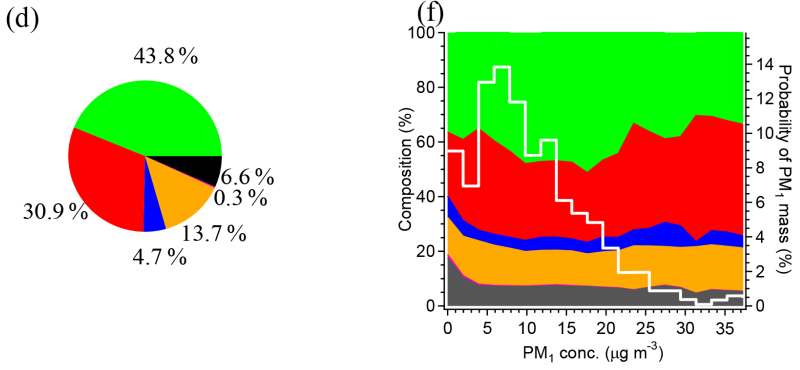

Figure 2. Time series of AMS species and BC at (a) NCB and (b) $\mathrm{SCB}$, the average $\mathrm{PM}_{1}$ chemical compositions at (c) NCB and (d) $\mathrm{SCB}$ (areas of pie charts are sized by $\mathrm{PM}_{1}$ mass loading), evolutions of $\mathrm{PM}_{1}$ compositions (left axis) as a function of $\mathrm{PM}_{1}$ mass loading, and the probability distributions of $\mathrm{PM}_{1}$ mass loading (white line to right axis) at (e) NCB and (f) SCB.

$\mathrm{NH}_{4} \mathrm{NO}_{3}$ at the beginning and the end of the campaigns and the results show stable values: at $\mathrm{NCB}$, the calibration $R_{\mathrm{NH}_{4} \mathrm{NO}_{3}}$ was 2.68 and 2.59 at the beginning and the end of the campaign, respectively; at SCB, this was 3.40 and 3.20 , respectively. We thus chose the average of the two IE calibrations as the $R_{\mathrm{NH}_{4} \mathrm{NO}_{3}}$ for each campaign, which was $2.61 \pm 0.13$ and $3.28 \pm 0.17$ at NCB and SCB, respectively, well within the range in the literature (Sato et al., 2010; Fry et al., 2013). The value for $R_{\mathrm{ON}}$ is more difficult to determine because it varies between instruments and precursor volatile organic compounds (VOCs). Fry et al. (2013) assumed that 
$R_{\mathrm{ON}} / R_{\mathrm{NH}_{4} \mathrm{NO}_{3}}$ is instrument-independent and further calculated its value to be $2.25 \pm 0.35$ based on the results of Farmer et al. (2010). However, only a few $R_{\mathrm{ON}} / R_{\mathrm{NH}_{4} \mathrm{NO}_{3}}$ values have been reported in the literature so far, such as $2.25 \pm 0.35$ for the organic nitrate standard (Farmer et al., 2010), $3.99 \pm 0.25$ for the organic nitrates produced from beta-pinene (Boyed et al., 2015), and $2.08 \pm 0.14$ for isoprene (Bruns et al., 2010). Sato et al. (2010) showed that the $R_{\mathrm{ON}} / R_{\mathrm{NH}_{4} \mathrm{NO}_{3}}$ for the organic nitrate through photooxidation of aromatics is about 2.45. Thus, only a $R_{\mathrm{ON}} / R_{\mathrm{NH}_{4} \mathrm{NO}_{3}}$ estimation range (from 2.08 to 3.99) can be defined from the literature due to the variation in precursor VOCs. In this study, the small difference between $R_{\mathrm{obs}}(2.79 \pm 0.63)$ and $R_{\mathrm{NH}_{4} \mathrm{NO}_{3}}(2.61 \pm 0.13)$ at NCB indicated a limited fraction of organic nitrates in the total nitrate with consideration of the uncertainty. However, at $\mathrm{SCB}, R_{\mathrm{obs}}(5.39 \pm 1.73)$ was significantly higher than $R_{\mathrm{NH}_{4} \mathrm{NO}_{3}}(3.28 \pm 0.17)$, implying significant existence of organic nitrates. A low measured / predicted $\mathrm{NH}_{4}^{+}$ratio $(\sim 0.94)$ at $\mathrm{SCB}$ was another implication for the presence of organic nitrates. In contrast to the abundant existence of metal nitrates in coarse mode particles (Huang et al., 2006), e.g., $\mathrm{NaNO}_{3}$, one may assume low contributions of metal nitrates in AMS detection in the submicron range. Thus, the lower and upper limits of $R_{\mathrm{ON}}$ were calculated to be 6.82 and 13.08 , respectively, to estimate the amount of organic nitrates at SCB in Sect. 3.2.

\subsection{TPSCF analysis}

PSCF analysis is a receptor model that explicitly incorporates meteorological information in the analysis scheme to produce a probability field for source emission potential. Cheng et al. (1993) improved the method by considering the influence of different height layers, called TPSCF analysis. In this study, air mass back-trajectories from the previous $48 \mathrm{~h}$ were determined using the Hybrid Single-Particle Lagrangian Integrated Trajectory model (version 4.9; Draxler and Rolph, 2003) at five different endpoint heights $(100,200,300,400$, and $500 \mathrm{~m}$ ) and a time interval of $1 \mathrm{~h}$ for each day. After that, the geographic region covered by the trajectories was divided into an array of $0.5 \times 0.5$ grid cells. The number of the trajectory segment endpoints over the $i j$ th grid cell for height $k$ is counted as $n_{i j}^{k}$. The number of these endpoints corresponding to a pollutant concentration higher than a criterion value for height $k$ is counted as $m_{i j}^{k}$. The mean value for each species was set as the pollution criterion. In order to reduce the effect of small values of $n_{i j}^{k}$, the TPSCF values were multiplied by an arbitrary weight function $W_{\sum n_{i j}^{k}}$ to better reflect the uncertainty in the values for these cells (Kedia et al., 2012; Wu et al., 2009; Zhu et al., 2011). In this case, we use the power of the number of trajectories $(T)$ at one endpoint height to determine the categories of $\sum n_{i j}^{k}$, and $W_{\sum n_{i j}^{k}}$ was defined

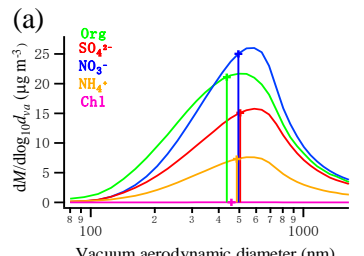

(c)

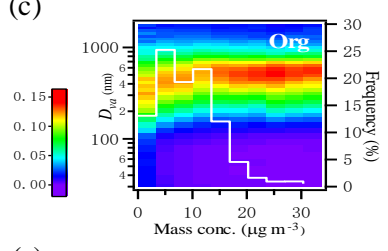

(e)
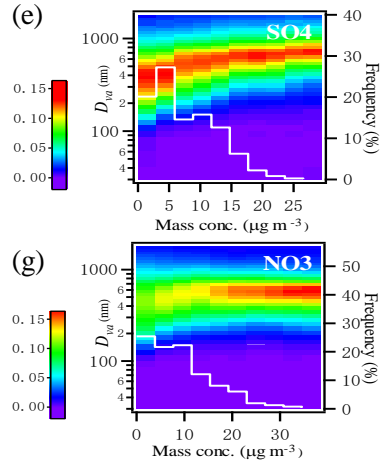

(d)
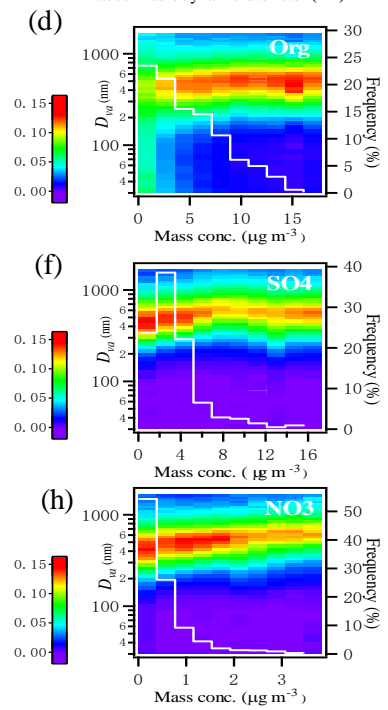

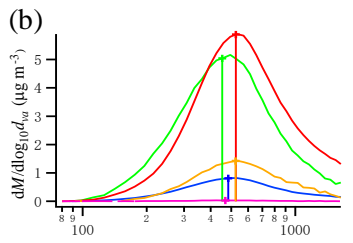

Figure 3. Average size distributions of AMS species, together with MMD (vacuum aerodynamic diameter) at (a) NCB and (b) SCB, as well as variation in normalized size distribution as a function of component mass concentration at (c, e, g) NCB and (d, f, h) SCB.

as below (Guo et al., 2015):

$W_{\sum n_{i j}^{k}}=\left\{\begin{array}{l}1.00, T^{0.7}<\sum n_{i j}^{k} \\ 0.70, T^{0.56}<\sum n_{i j}^{k} \leq T^{0.7} \\ 0.42, T^{0.42}<\sum n_{i j}^{k} \leq T^{0.56} \\ 0.05, \sum n_{i j}^{k} \leq T^{0.42} .\end{array}\right.$

\section{Results and discussion}

\section{1 $\mathrm{PM}_{1}$ composition and size distribution}

Figure $2 \mathrm{a}$ and $\mathrm{b}$ show the time series of the $\mathrm{PM}_{1}$ mass concentrations of different components during the two campaigns, respectively. The average $\mathrm{PM}_{1}$ mass concentration (sum of the measured species) was $36.8 \pm 19.8 \mu \mathrm{g} \mathrm{m}^{-3}$ (mean $\pm \mathrm{SD}$ ) at $\mathrm{NCB}$ (varying from 2.9 to $111.1 \mu \mathrm{g} \mathrm{m}^{-3}$ ), which is much higher than that observed at SCB $\left(10.9 \pm 7.8 \mu \mathrm{g} \mathrm{m}^{-3}\right.$, varying from 0.1 to $\left.41.6 \mu \mathrm{g} \mathrm{m}^{-3}\right)$. This indicates that there was more severe aerosol pollution in the northern region than in the southern region in China. The chemical composition of $\mathrm{PM}_{1}$ was dominated by $\mathrm{OA}$ $(27.2 \%)$, nitrate $(26.7 \%)$, and sulfate $(22.0 \%)$ at $\mathrm{NCB}$, while at SCB, OA (43.5\%), and sulfate $(30.5 \%)$ were the two most 

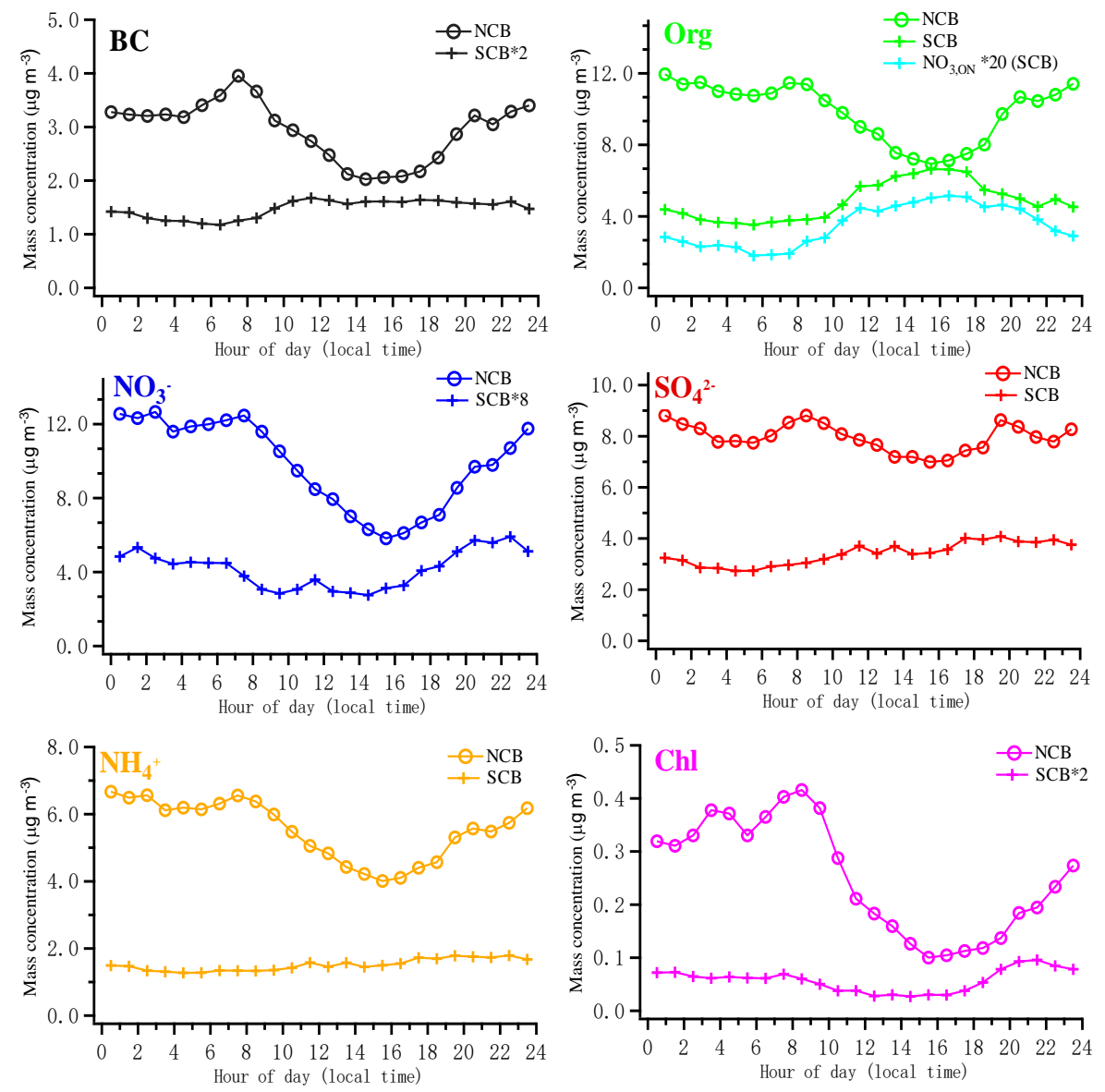

Figure 4. Diurnal variations in $\mathrm{PM}_{1}$ components at $\mathrm{NCB}$ and $\mathrm{SCB}$.

abundant $\mathrm{PM}_{1}$ components of the total mass, as shown in Fig. $2 \mathrm{c}$ and d. Nitrate only contributed $4.7 \%$ to the total $\mathrm{PM}_{1}$ mass at $\mathrm{SCB}$, suggesting that $\mathrm{NO}_{x}$ emissions had a minor influence here in comparison with that at NCB. In addition, the higher ambient temperature (as shown in Table 1) at SCB would lead to more aerosol-to-gas partitioning of the semivolatile nitrate. Note that the $\mathrm{BC}$ mass fractions in $\mathrm{PM}_{1}$ in Fig. $2 \mathrm{c}$ and $\mathrm{d}$ are likely to be overestimated because $\mathrm{BC}$ was measured for $\mathrm{PM}_{2.5}$ by an Aethalometer. This overestimation could be less than $20 \%$ according to the ambient BC size distributions measured at an urban site in southern China (Lan et al., 2011).

Figure $2 \mathrm{e}$ and $\mathrm{f}$ represent the variation in relative contributions of different species as a function of the total $\mathrm{PM}_{1}$ mass concentration at the two background sites. It is found that nitrate shows a continuously increasing fraction when $\mathrm{PM}_{1}$ was accumulating at $\mathrm{NCB}$, while both sulfate and $\mathrm{OA}$ played an important role when $\mathrm{PM}_{1}$ was accumulating at SCB. This implies that $\mathrm{NO}_{x}$ emissions played a critical role in regional air pollution in the more polluted northern China.

In terms of particle size distribution, all species at the two background sites generally show a similar accumulation mode, with a mass median diameter (MMD, vacuum aerodynamic diameter) at a large size of $\sim 550 \mathrm{~nm}$ in vacuum aerodynamic diameter $\left(D_{\text {va }}\right)$ (Fig. 3a and b), which indicates very aged and internally mixed aerosol particles (Jimenez et al., 2003; Huang et al., 2010). In comparison to the size distribution patterns observed previously in urban atmospheres in China, the size distributions of OA at the two sites had a much smaller mass "hump" around 200-300 nm, which typically represents freshly emitted particles (Huang et al., 2010, 2012; He et al., 2011). These size distribution patterns indicated few fresh local emissions at the two background sites. Figure $3 \mathrm{c}-\mathrm{h}$ show the variation in normalization size distribution as a function of component mass concentration. With the mass concentration increasing, the size distributions of $\mathrm{OA}$, sulfate, and nitrate at the two sites become concentrated in larger sizes, further confirming that the high pollution levels there were determined by the regional transport of aged particles.

\subsection{Estimation of organic nitrates}

Organic nitrates are a less explored but potentially important component of secondary organic aerosol. Most atmo- 
spheric organic nitrates are produced by either photochemical (OH-initiated) or nocturnal $\left(\mathrm{NO}_{3}\right.$-initiated) oxidation reactions of anthropogenic and biogenic volatile organic compounds (Farmer et al., 2010). Recently, several direct and indirect approaches have been proposed to estimate organic nitrates from direct measurement data (Rollins et al., 2012; Farmer et al., 2010; Xu et al., 2015b). Xu et al. (2015b) estimated organic nitrates based on HR-ToF-AMS data and showed that organic nitrates contribute about $5-12 \%$ of the total OA for summer datasets and $9-25 \%$ of the total OA for winter datasets in the southeastern USA. However, similar studies on the contribution of organic nitrates to total OA in China have not yet been seen. As noted in Sect. 2.4, estimation of organic nitrates at NCB was not plausible using the $\mathrm{NO}^{+} / \mathrm{NO}_{2}^{+}$method because of the low $\mathrm{NO}_{x}^{+}$ratios observed for the ambient aerosol, which indicates that organic nitrates were negligible in comparison with the large amount of inorganic nitrate (Farmer et al., 2010) At SCB, the time series of ambient $\mathrm{NO}^{+} / \mathrm{NO}_{2}^{+}$ratio $\left(R_{\mathrm{obs}}\right)$ are within the range of the calibrated value (i.e., $\left.R_{\mathrm{NH}_{4} \mathrm{NO}_{3}}, 3.28\right)$ and the maximum value (i.e., $R_{\mathrm{ON}}, 13.08$ ), making the estimation of organic nitrates at SCB possible. Although the concentrations of organic nitrates at NCB might not be smaller than at SCB, it is harder to quantify organic nitrates at NCB because ammonium nitrate at NCB was much higher than at $\mathrm{SCB}$, so that the uncertainties with this method are much higher. The results obtained using the $\mathrm{NO}_{x}^{+}$ratio method described in Sect. 2.4 are presented in Table 2. The mass fraction of the nitrate functionality from organic nitrates (i.e., $\mathrm{NO}_{3, \mathrm{ON}} / \mathrm{NO}_{3, \mathrm{obs}}$ ) was found to be $15-22 \%$ at SCB. Furthermore, by assuming that the average molecular weights of particle-phase organic nitrates are $200-300 \mathrm{~g} \times \mathrm{mol}^{-1}$ (Rollins et al., 2012), the calculation indicated that organic nitrates contributed $5-11 \%$ to the total OA at SCB. These results indicated that organic nitrates existed significantly in aerosol particles at SCB.

\subsection{Diurnal patterns of $\mathrm{PM}_{1}$ species}

The mean diurnal variations in $\mathrm{PM}_{1}$ components at the two background sites are shown in Fig. 4. BC at NCB shows lower concentrations in the daytime, while it shows higher concentrations in the daytime at SCB. This should be attributed to the different altitudes of the two sites: when the planetary boundary layer (PBL) is uplifted in the daytime, near-ground pollutants are transported vertically to the upper atmosphere, and thus the $\mathrm{BC}$ concentrations at high attitudes increase, while those near the ground decrease. The small BC peak in the early morning at NCB could be attributed to the influence of highway traffic emissions in a local scale, which increased quickly in the early morning. The diurnal patterns of OA, nitrate, sulfate, ammonium, and chloride generally show similar trends to those of $\mathrm{BC}$ at $\mathrm{NCB}$, mainly driven by the diurnal variation in PBL. At SCB, OA shows much higher daytime concentrations in comparison with the diurnal pat- tern of BC due to photochemical formation, as supported by the simultaneous trend of the secondary species, that is, organic nitrates (in Fig. 4), while the secondary formation of nitrate seemed not to compensate for its mass loss due to the particle-to-gas vaporization of $\mathrm{NH}_{4} \mathrm{NO}_{3}$ during the daytime. Note that, at either NCB or SCB, the diurnal variation in sulfate was not as great as the others species, suggesting that sulfate was well mixed through the boundary layer.

\subsection{Organic aerosol aging process}

Figure 5 shows the Van Krevelen diagrams $(\mathrm{H} / \mathrm{C}$ versus $\mathrm{O} / \mathrm{C}$ ) of $\mathrm{OA}$ at $\mathrm{NCB}$ and $\mathrm{SCB}$. The average $\mathrm{O} / \mathrm{C}$ ratio at SCB was 0.98 , which was much higher than that at NCB (0.67), indicating that $\mathrm{OA}$ in southern China was generally more oxidized and aged. Some campaign-average O / C and $\mathrm{H} / \mathrm{C}$ ratios observed at urban sites in China by our group (Huang et al., 2010, 2012; He et al., 2011) and at remote/background sites in the literature (Chen et al., 2009, 2015; Robinson et al., 2011) are also plotted in Fig. 5, and all the values in the literature have been corrected by the "Improved-Ambient" method described in Canagaratna et al. (2015). Noted that both $\mathrm{O} / \mathrm{C}$ and $\mathrm{H} / \mathrm{C}$ calculated with the Improved-Ambient method (Canagaratna et al., 2015) should be higher than those using the previous method (Aiken et al., 2008) due to the underestimation of intensities of the $\mathrm{H}_{2} \mathrm{O}^{+}$and/or $\mathrm{CO}^{+}$fragments by the previous method. A comparison of the elemental ratios in our previous campaigns in China between the previous and ImprovedAmbient methods can be found in Table S1 in the Supplement. The $\mathrm{O} / \mathrm{C}$ and $\mathrm{H} / \mathrm{C}$ ratios at $\mathrm{SCB}$ and $\mathrm{NCB}$ were found to be closer to those at other remote/background sites but further from those at the urban sites, consistent with SCB and NCB being background sites. Heald et al. (2010) proposed using the Van Krevelen diagram to illustrate how reactions involving addition of functional groups fall along straight lines for ambient aerosol. Although many other factors, such as the mixing of different air masses and components/sources, may also lead to a variety of slopes in the Van Krevelen diagram in the case of ambient field measurements, the Van Krevelen diagram may still be useful for constraining reactions that are responsible for the aging of OA (Hayes et al., 2013). The $\mathrm{O} / \mathrm{C}$ versus $\mathrm{H} / \mathrm{C}$ points at the two sites were fitted using the reduced-major-axis regression method (Smith, 2009), which is considered to be the best fit for a bivariate relationship when the variable represented on the $x$ axis is measured with error. The fitted lines at NCB and SCB agreed with each other very well and have a common slope of about -0.7 , implying that the continuous oxidation processes of OA were controlled by mixed mechanisms, such as the formation of carboxylic acids with or without fragmentation, alcohol, and carbonyl addition (Heald et al., 2010), and would follow this empirical line in the Van Krevelen diagram in both northern and southern China. Note that the organic aerosol observed at SCB is very highly oxy- 
Table 2. Results of organic nitrates estimated using the $\mathrm{NO}_{x}^{+}$ratio method.

\begin{tabular}{|c|c|c|c|c|c|c|c|c|}
\hline \multirow[t]{2}{*}{ Site } & \multirow[t]{2}{*}{$\mathrm{R}_{\mathrm{NH}_{4} \mathrm{NO}_{3}}$} & \multirow[t]{2}{*}{$\mathrm{R}_{\mathrm{obs}}$} & \multicolumn{2}{|c|}{$\begin{array}{l}\mathrm{NO}_{3, \mathrm{ON}} \text { conc. } \\
\quad\left(\mu \mathrm{g} \mathrm{m}^{-3}\right)\end{array}$} & \multicolumn{2}{|c|}{$\mathrm{NO}_{3, \mathrm{ON}} / \mathrm{NO}_{3, \mathrm{obs}}$} & \multicolumn{2}{|c|}{$\mathrm{ON} / \mathrm{OA}$} \\
\hline & & & lower & upper & lower & upper & lower & upper \\
\hline $\mathrm{NCB}$ & $2.61 \pm 0.13$ & $2.79 \pm 0.63$ & - & - & - & - & - & - \\
\hline $\mathrm{SCB}$ & $3.28 \pm 0.17$ & $5.39 \pm 1.73$ & 0.08 & 0.12 & $15 \%$ & $22 \%$ & $5 \%$ & $11 \%$ \\
\hline
\end{tabular}

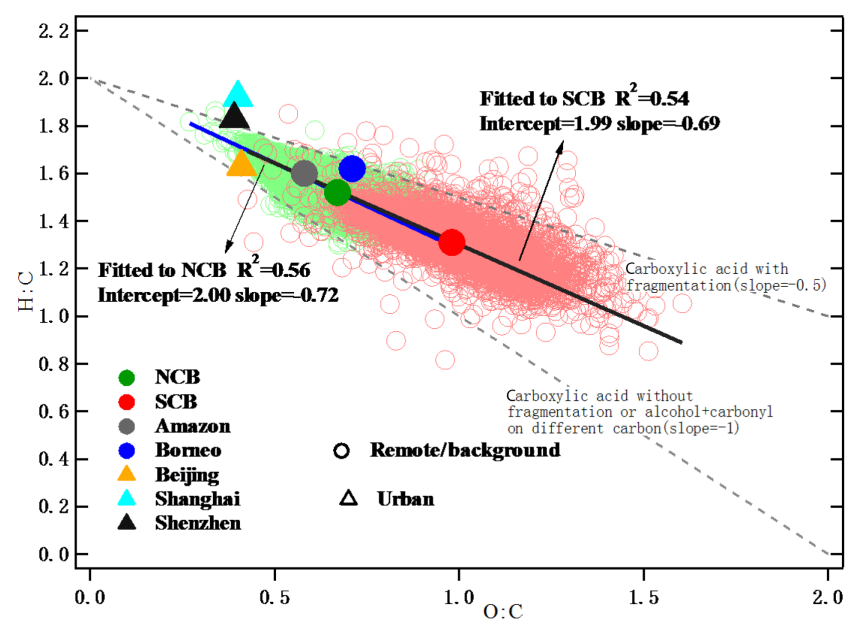

Figure 5. Van Krevelen diagrams $(\mathrm{H} / \mathrm{C}$ versus $\mathrm{O} / \mathrm{C})$ of $\mathrm{OA}$ at NCB (light green) and SCB (light red). The campaign-average $\mathrm{O} / \mathrm{C}$ and $\mathrm{H} / \mathrm{C}$ ratios of remote/background and urban sites in the literature are also included.

genated compared to the ambient data ever reported in the literature, consistent with the previous finding that the atmospheric oxidizing capacity in southern China is unexpectedly high (Hofzumahaus et al., 2009).

\subsection{Organic aerosol source apportionment}

Three organic components, including a hydrocarbon-like OA (HOA) and two oxygenated OA (OOA1 and OOA2), at NCB were identified using the PMF method described in Sect. 2.3. While at SCB, only two oxygenated OA components (SVOOA and LV-OOA) were identified. In this case, the contribution of primary organic aerosol (POA) might be too small for PMF to identify. At a remote site in a boreal forest in Finland and a rural site in the southeastern USA, no POA factor was identified by PMF either (Raatikainen et al., 2010; Xu et al., 2015a).

Figure $6 \mathrm{a}$ and $\mathrm{b}$ show the MS profiles of the OA factors and Figs. $6 \mathrm{c}$ and $6 \mathrm{~d}$ present their time series during the two campaigns. At NCB, HOA, OOA1, and OOA2 on average accounted for $30.6,48.6$, and $20.8 \%$ of the total OA mass, respectively. The HOA factor with a low $\mathrm{O} / \mathrm{C}$ ratio of 0.28 was primarily dominated by the ion series of $\mathrm{C}_{x} \mathrm{H}_{y}^{+}$and showed a good correlation with $\mathrm{BC}\left(R^{2}=0.51\right)$, indicating that it was directly emitted from fossil fuel combustion (Zhang et al., 2005; Jimenez et al., 2009). Note that $f 44$ is a little bit higher than $f 28$ in the MS profile of HOA, suggesting that HOA is likely mixed with some OOA that cannot be separate by PMF and thus the actual contribution of HOA could be lower. The sum of OOA1 and OOA2 showed a high correlation with the sum of sulfate and nitrate $\left(R^{2}=0.76\right.$, in Fig. $\left.6 \mathrm{c}\right)$, confirming their secondary nature. Although the two OOA components at $\mathrm{NCB}$ had the similar O / C ratios of 0.89 (OOA1) and 0.86 (OOA2), their time series were significantly different, indicating their different source areas as discussed in Sect. 3.6. A similar case of OOA splitting was also found in the 2008 Beijing Olympic Games AMS dataset (Huang et al., 2010). At $\mathrm{SCB}$, the OA factor with a higher $\mathrm{CO}_{2}^{+}$fraction and $\mathrm{O} / \mathrm{C}$ is more oxidized and aged, and is thus referred to as LV-OOA, while the $\mathrm{OA}$ factor with a lower $\mathrm{CO}_{2}^{+}$fraction and $\mathrm{O} / \mathrm{C}$ is less oxidized and fresher, and is thus referred to as SV-OOA (Jimenez et al., 2009; $\mathrm{Ng}$ et al., 2010). SV-OOA and LVOOA on average contributed 39.3 and $60.7 \%$ of the total OA mass, respectively. Although many previous AMS measurements at urban and rural sites (Lanz et al., 2007; Ulbrich et al., 2009; He et al., 2011; Huang et al., 2012) found that SVOOA and LV-OOA correlated well with nitrate and sulfate, respectively, most likely due to their common volatile nature (Jimenez et al., 2009; Ng et al., 2010), these correlations were not significant enough at $\mathrm{SCB}\left(R^{2}=0.40\right.$ and 0.24 , respectively). Since the SV-OOA at SCB is a more aged one with a higher $\mathrm{O} / \mathrm{C}$ ratio in comparison with the SV-OOA factors in previous measurements, its semi-volatility might not be similar to that of nitrate. On the other hand, the different source regions of LV-OOA and sulfate, as discussed in the next section, may explain their inconsistent temporal variations. Instead, it is very interesting to find that $\mathrm{BC}$ was correlated well with both SV-OOA and LV-OOA (both $\left.R^{2}=0.67\right)$, and even better with the total OA $\left(R^{2}=0.72\right)$ at SCB, suggesting that the OOA precursors and BC should have the same sources. Considering the special location of the SCB site, the most likely sources of BC were biomass burning and ship emissions, as discussed in Sect. 3.6.

As shown in Fig. $6 \mathrm{~g}$ and $\mathrm{h}$, the average diurnal patterns of the two OOA components at NCB show lower concentrations in the daytime while the two OOA components at SCB show higher concentrations in the daytime, mainly due to the influ- 


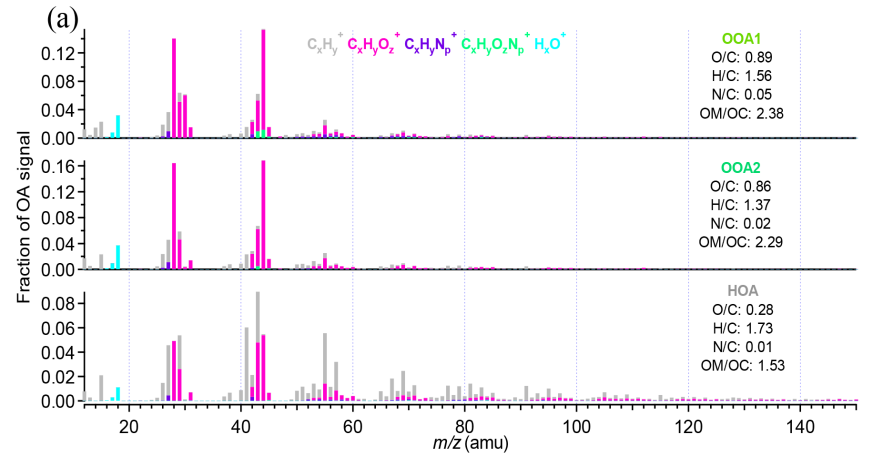

(b)
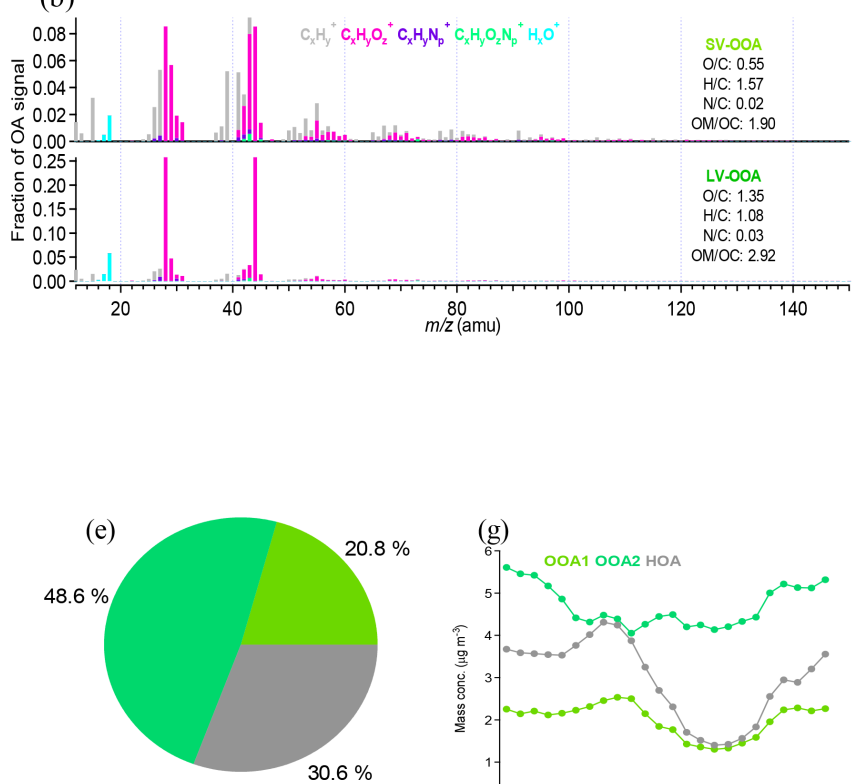

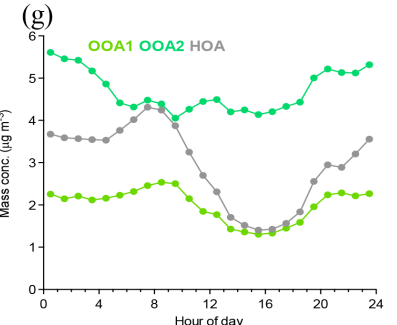

(c)

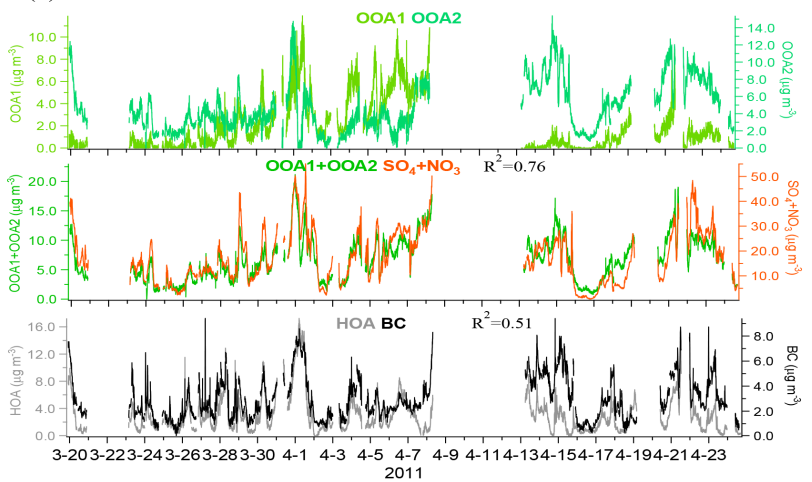

(d)

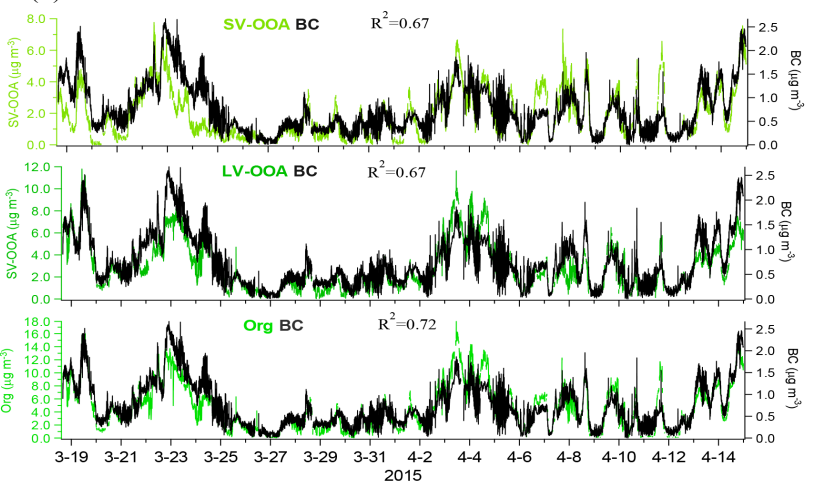

(f)

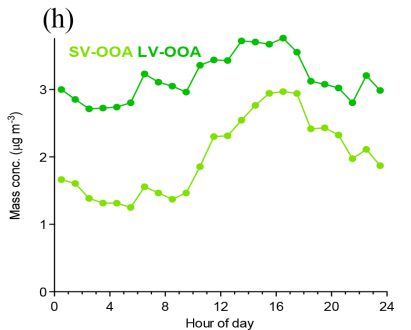

Figure 6. Mass spectrum profiles of the OA components at (a) NCB and (b) SCB identified by PMF. The time series of the OA components at (c) NCB and (d) SCB and other relevant species, the averages of the OA compositions at (e) NCB and (f) SCB, and the diurnal patterns of the OA components at (g) NCB and (h) SCB.

ence of PBL, as discussed in Sect. 3.3. The small early morning peak of HOA at $\mathrm{NCB}$ was similar to $\mathrm{BC}$, due to the influence of highway traffic emissions in a local scale. At SCB, LV-OOA shows a milder diurnal trend than SV-OOA, consistent with it being a more aged OA component and better mixed in PBL. In addition, the dramatic increase in SV-OOA in the daytime at SCB is similar to that in organic nitrates (in Fig. 4), implying that organic nitrates are mostly associated with SV-OOA and both of them are largely formed in the daytime.

\subsection{Potential emission source area analysis}

The potential source areas identified by the TPSCF model for different aerosol components at both sites are shown in Fig. 7. At NCB, the high-potential source region of $\mathrm{BC}$ was mainly located in the southern continental areas, including the highly urbanized and industrialized Yangtze River Delta (YRD) region and the region of the middle reaches of the Yangtze River. The HOA high-potential source area was similar but smaller compared to that of BC, which is a reasonable result of the poorer stability and thus shorter lifetime of HOA. For secondary species, including OOA, nitrate, and sulfate, besides the YRD region, the sea area to the east of YRD, extending to South Korea, also played an important role. In addition, we can clearly see that the high-potential source areas of OOA1 and OOA2 were substantially different: OOA2 is mostly mainland-oriented, similar to HOA and $\mathrm{BC}$, while OOA1 is uniquely from the sea area between China and South Korea. Ship emissions are reasonably assumed to be the responsible source from the sea, since the 
(a)
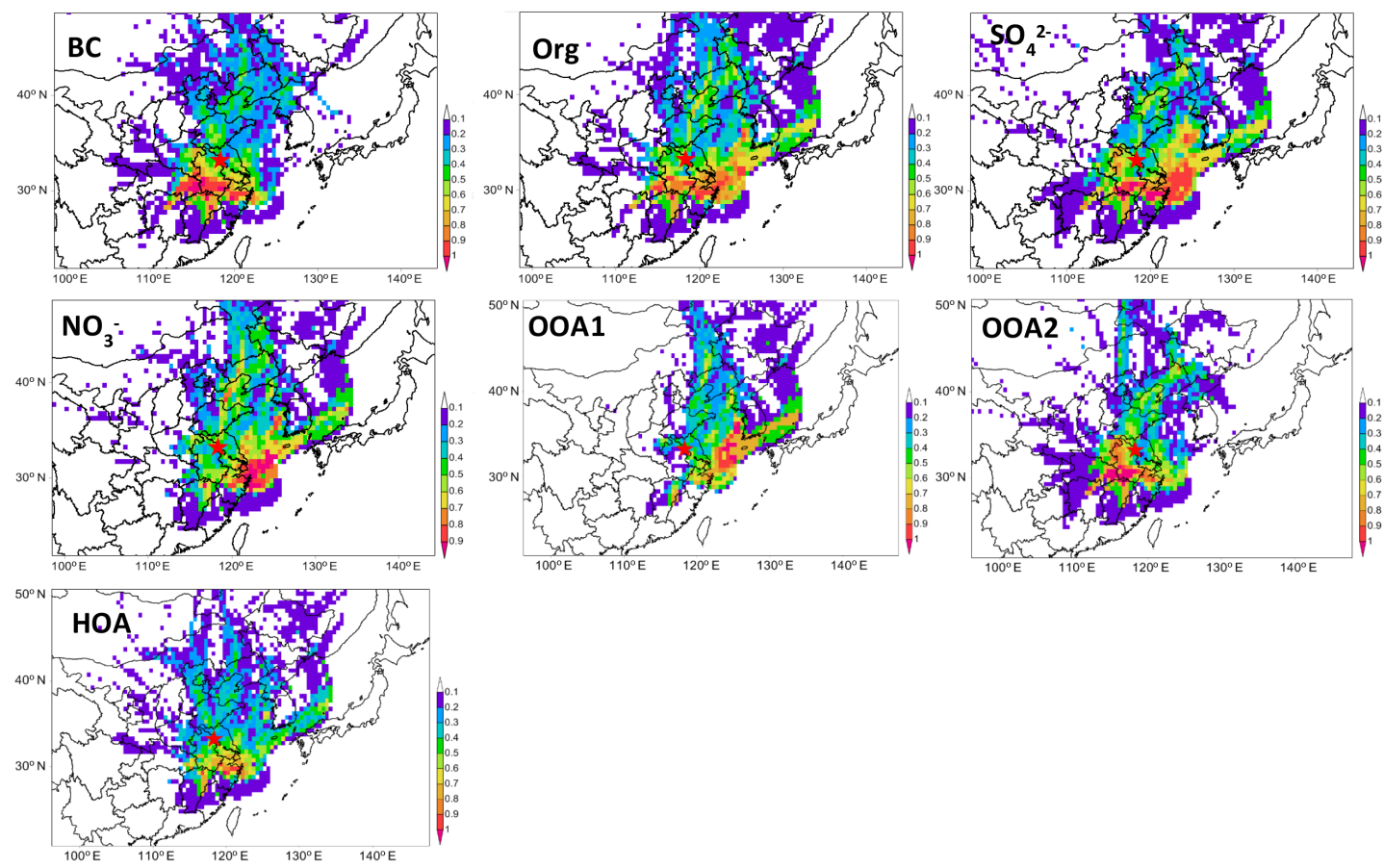

(b)
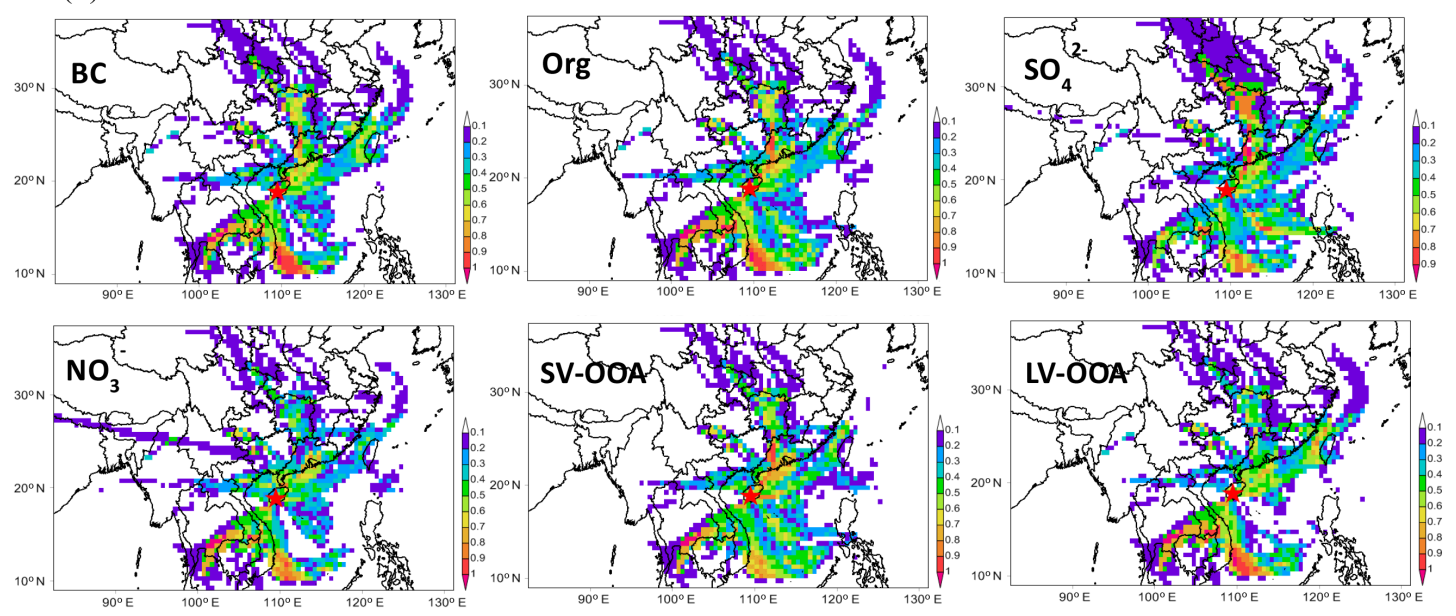

Figure 7. Mapping of the TPSCF results of major aerosol species at (a) NCB and (b) SCB.

YRD area has 2 of the 10 biggest ports in the world, that is, the Shanghai port and the Ningbo-Zhoushan port. The engines of ocean ships typically consume heavy fuel oils, emitting huge amounts of $\mathrm{NO}_{x}, \mathrm{SO}_{2}, \mathrm{VOCs}$, and particles, and are thus regarded as an important source of air pollution on a regional scale (Eyringa et al., 2010).

At SCB, BC, OA, sulfate, and nitrate all have three similar potentially important source areas. The first one is the boundary area among Laos, Cambodia, and Thailand, where biomass burning emissions are intensive in the spring season (Lin et al., 2013); Chuang et al. (2014) recently attributed high levels of carbonaceous aerosol in the background of Tai- wan in spring to biomass burning in the Indochinese Peninsula. The second one is the sea area to the southeast of Vietnam, which is a key international water course for cargo ships going between East Asia and Europe, which also contains the biggest harbor in southern Vietnam. The third one is the northern mainland area, mainly in the adjacent and economically developed Guangdong Province. Based on radiocarbon $\left({ }^{14} \mathrm{C}\right)$ measurements at another regional background site very close to our SCB site on the Hainan Island, Zhang et al. (2014) also found that a higher contribution of fossil sources could be attributed to emissions from southeastern China, while an increase in non-fossil sources was as- 
sociated with open biomass burning activities in Southeast Asian countries. In comparison with other species, it is found that sulfate had more potential source areas in inland China, where coal is intensively used and $\mathrm{SO}_{2}$ emissions are high, rather than in the Southeast Asian countries. As at NCB, LVOOA at SCB had more intensive source areas from the sea than SV-OOA, implying that ship emissions can produce a large amount of very aged OA after regional transport and serve as a big contributor to regional background aerosol levels.

In summary, it is seen that the potential pollution source areas of the two background sites in China are on a regional scale rather than on a local scale, consistent with their nature as background sites. This highlights the need of longterm AMS measurements for all seasons at multiple sites in East Asia in order to have a comprehensive understanding of aerosol sources and transport in this region. Crippa et al. (2014) recently showed the advantages of multiplesite AMS measurements in acquiring insights into organic aerosol sources in Europe. In addition, note that the source areas are located not only in the Chinese territory but also in other neighboring countries, and biomass burning and ship emissions are found to be the likely sources causing crossboundary air pollutant transport from neighboring countries to China.

\section{Conclusions}

Based on the HR-ToF-AMS measurements at two national background sites in southern and northern China during spring, the average $\mathrm{PM}_{1}$ at $\mathrm{NCB}\left(36.8 \pm 19.8 \mu \mathrm{g} \mathrm{m}^{-3}\right)$ was found to be much higher than that at SCB $\left(10.9 \pm 7.8 \mu \mathrm{g} \mathrm{m}^{-3}\right)$, suggesting more severe aerosol pollution in the northern part of China. At SCB, OA (43.5\%) and sulfate $(30.5 \%)$ were the most abundant $\mathrm{PM}_{1}$ components, while nitrate contributed only a small fraction $(4.7 \%)$. At NCB, however, nitrate accounted for a comparable fraction $(26.7 \%)$ of $\mathrm{PM}_{1}$ mass to that of $\mathrm{OA}(27.2 \%)$ and sulfate $(22.0 \%)$, revealing that northern China was much more influenced by $\mathrm{NO}_{x}$ emissions. The average size distribution patterns of the species (except BC) at both sites were all dominated by an accumulation mode peaking at $\sim 550 \mathrm{~nm}$, indicating very aged particles. By using the $\mathrm{NO}_{x}^{+}$ratio method, organic nitrate was estimated to account for $15-22 \%$ of the total nitrate at SCB but only a negligible fraction at NCB. $\mathrm{OA}$ at $\mathrm{SCB}$ was found to be more oxidized $(\mathrm{O} / \mathrm{C}=0.98)$ than that at $\mathrm{NCB}(\mathrm{O} / \mathrm{C}=0.67)$ by organic elemental analysis, which was a reasonable result when considering the very high atmospheric oxidizing capacity in southern China.

PMF analysis of the high-resolution organic mass spectral data identified primarily emitted HOA and secondarily formed OOA1 and OOA2 with different source areas at NCB, while only secondary SV-OOA and LV-OOA at SCB. OOA2 $(48.6 \%)$ and LV-OOA $(60.7 \%)$ dominated the OA mass at NCB and SCB, respectively. The diurnal variation analysis suggested that SV-OOA, likely containing a major part of organic nitrate, was largely formed in the daytime at SCB. TPSCF results of the major species of $\mathrm{PM}_{1}$ at both $\mathrm{NCB}$ and $\mathrm{SCB}$ showed sources on a large regional scale. Besides mainland China, some territories of neighboring countries were also high-potential source areas, with biomass burning and cargo ship emissions as the most likely responsible sources for this cross-boundary air pollution.

\section{Data availability}

Datasets are available by contacting the corresponding author, Xiao-Feng Huang (huangxf@pku.edu.cn).

\section{The Supplement related to this article is available online at doi:10.5194/acp-16-10283-2016-supplement.}

Acknowledgements. This work was supported by the National Natural Science Foundation of China $(21277003,91544215)$ and the Ministry of Environmental Protection of China (Special Fund for Public Welfare 201309016).

Edited by: A. S. H. Prevot

Reviewed by: two anonymous referees

\section{References}

Aiken, A. C., Decarlo, P. F., Kroll, J. H., Worsnop, D. R., Huffman, J. A., Docherty, K. S., Ulbrich, I. M., Mohr, C., Kimmel, J. R., Sueper, D., Sun, Y., Zhang, Q., Trimborn, A., Northway, M., Ziemann, P. J., Canagaratna, M. R., Onasch, T. B., Alfarra, M. R., Prevot, A. S. H., Dommen, J., Duplissy, J., Metzger, A., Baltensperger, U., and Jimenez, J. L.: O / C and OM / OC ratios of primary, secondary, and ambient organic aerosols with high resolution time-of-flight aerosol mass spectrometry, Environ Sci. Technol., 42, 4478-4485, doi:10.1021/Es703009q, 2008.

Boyd, C. M., Sanchez, J., Xu, L., Eugene, A. J., Nah, T., Tuet, W. Y., Guzman, M. I., and Ng, N. L.: Secondary Organic Aerosol (SOA)formation from the $\beta$-pinene $+\mathrm{NO}_{3}$ system: effect of humidity and peroxy radical fate, Atmos. Chem. Phys., 15, 74977522, doi:10.5194/acp-15-7497-2015, 2015.

Bruns, E. A., Perraud, V., Zelenyuk, A., Ezell, M. J., Johnson, S. N., Yu, Y., Imre, D., Finlayson-Pitts, B. J., and Alexander, M. L.: Comparison of FTIR and Particle Mass Spectrometry for the Measurement of Particulate Organic Nitrates, Environ. Sci. Technol., 44, 1056-1061, 2010.

Canagaratna, M. R., Jayne, J. T., Jimenez, J. L., Allan, J. D., Alfarra, M. R., Zhang, Q., Onasch, T. B., Drewnick, F., Coe, H., Middlebrook, A., Delia, A., Williams, L. R., Trimborn, A. M., Northway, M. J., DeCarlo, P. F., Kolb, C. E., Davidovits, P., and Worsnop, D. R.: Chemical and microphysical characterization of 
ambient aerosols with the aerodyne aerosol mass spectrometer, Mass Spectr. Rev., 26, 185-222, 2007.

Canagaratna, M. R., Jimenez, J. L., Kroll, J. H., Chen, Q., Kessler,S. H., Massoli, P., Hildebrandt Ruiz, L., Fortner, E., Williams, L.R., Wilson, K. R., Surratt, J. D., Donahue, N. M., Jayne, J. T., and Worsnop, D. R.: Elemental ratio measurements of organic compounds using aerosol mass spectrometry: characterization, improved calibration, and implications, Atmos. Chem. Phys., 15, 253-272, doi:10.5194/acp-15-253-2015, 2015.

Chuang, M., Lee, C., Chou, C.C.K., Lin, N., Sheu, G., Wang, J., Chang, S., Wang, S., Chi, K. H., Young, C., Huang, H., Chen, H., Weng, G., Lai, S., Hsu, S., Chang, Y., Chang, J., and Wu, $\mathrm{X}$. Carbonaceous aerosols in the air masses transported from Indochina to Taiwan: Long-term observation at Mt. Lulin, Atmos. Environ., 89, 507-516, 2014.

Chen, Q., Farmer, D. K., Schneider, J., Zorn, S. R., Heald, C. L., Karl, T.G., Guenther, A., Allan, J. D., Robinson, N., Coe, H., Kimmel, J. R., Pauliquevis, T., Borrmann, S., Pöschl, U., Andreae, M. O., Artaxo, P., Jimenez, J. L., and Martin, S. T.: Mass spectral characterization of submicron biogenic organic particles in the Amazon Basin, Geophys. Res. Lett., 36, L20806, doi:10.1029/2009GL039880, 2009.

Chen, Q., Farmer, D. K., Rizzo, L. V., Pauliquevis, T., Kuwata, M., Karl, T. G., Guenther, A., Allan, J. D., Coe, H., Andreae, M. O., Pöschl, U., Jimenez, J. L., Artaxo, P., and Martin, S. T.: Submicron particle mass concentrations and sources in the Amazonian wet season (AMAZE-08), Atmos. Chem. Phys., 15, 3687-3701, doi:10.5194/acp-15-3687-2015, 2015.

Cheng, M. D., Hopke, P. K., Barrie, L., Rippe, A., Olson, M., and Landsberger, S.: Qualitative Determination of Source Regions of Aerosol in Canadian High Arctic, Environ. Sci. Technol., 27, 2063-2071, 1993.

Crippa, M., Canonaco, F., Lanz, V. A., Aijala, M., Allan, J. D., Carbone, S., Capes, G., Ceburnis, D., Dall'Osto, M., Day, D. A., DeCarlo, P. F., Ehn, M., Eriksson, A., Freney, E., Ruiz, L. H., Hillamo, R., Jimenez, J. L., Junninen, H., Kiendler-Scharr, A., Kortelainen, A. M., Kulmala, M., Laaksonen, A., Mensah, A., Mohr, C., Nemitz, E., O'Dowd, C., Ovadnevaite, J., Pandis, S. N., Petaja, T., Poulain, L., Saarikoski, S., Sellegri, K., Swietlicki, E., Tiitta, P., Worsnop, D. R., Baltensperger, U., and Prevot, A. S. H.: Organic aerosol components derived from 25 AMS data sets across Europe using a consistent ME-2 based source apportionment approach, Atmos. Chem. Phys., 14, 6159-6176, doi:10.5194/acp-14-6159-2014, 2014.

DeCarlo, P. F., Kimmel, J. R., Trimborn, A., Northway, M. J., Jayne,J. T., Aiken, A. C., Gonin, M., Fuhrer, K., Horvath, T., Docherty,K. S., Worsnop, D. R., and Jimenez, J. L.: Field-Deployable, High-Resolution, Time-of-Flight Aerosol Mass Spectrometer, Anal. Chem., 78, 8281-8289, 2006.

Draxler, R. R. and Rolph, G. D.: HYSPLIT (Hybrid Single-Particle Lagrangian Integrated Trajectory) Model access via NOAA ARLREADY Website, http://www.arl.noaa.gov/ready/hysplit4. html, NOAA Air Resources Laboratory, Silver Spring, MD, 2003.

Drewnick, F., Hings, S. S., DeCarlo, P., Jayne, J. T., Gonin, M., Fuhrer, K., Weimer, S., Jimenez, J. L., Demerjian, K. L., Borrmann, S., and Worsnop, D. R.: A new time-of-flight aerosol mass spectrometer (TOF-AMS)-Instrument description and first field deployment, Aerosol Sci. Tech., 39, 637-658, 2005.
Du, W., Sun, Y. L., Xu, Y. S., Jiang, Q., Wang, Q. Q., Yang, W., Wang, F., Bai, Z. P., Zhao, X. D., and Yang, Y. C.: Chemical characterization of submicron aerosol and particle growth events at a national background site (3295 m a.s.1.) on the Tibetan Plateau. Atmos. Chem. Phys., 15, 10811-10824, doi:10.5194/acp-1510811-2015, 2015.

Elser, M., Huang, R. J., Wolf, R., Slowik, J. G., Wang, Q., Canonaco, F., Li, G., Bozzetti, C., Daellenbach, K. R., Huang, Y., Zhang, R., Li, Z., Cao, J., Baltensperger, U., El-Haddad, I., and Prévôt, A. S. H.: New insights into PM2.5 chemical composition and sources in two major cities in China during extreme haze events using aerosol mass spectrometry, Atmos. Chem. Phys., 16, 3207-3225, doi:10.5194/acp-16-3207-2016, 2016.

Eyringa, V., Isaksenb, I. S. A., Berntsenc, T., Collinsd, W. J., Corbette, J. J., Endresenf, O., Graingerg, R. G., Moldanovah, J., Schlagera, H., and Stevensoni, D. S.: Transport impacts on atmosphere and climate: Shipping, Atmos. Environ., 44, 4735-4771, 2010.

Farmer, D. K., Matsunaga, A., Docherty, K. S., Surratt, J. D., Seinfeld, J. H., Ziemann, P. J., and Jimenez, J. L.: Response of an aerosol mass spectrometer to organonitrates and organosulfates and implications for atmospheric chemistry, P. Natl. Acad. Sci. USA, 107, 6670-6675, 2010.

Fry, J. L., Kiendler-Scharr, A., Rollins, A. W., Wooldridge, P.J., Brown, S. S., Fuchs, H., Dubé, W., Mensah, A., dal Maso, M., Tillmann, R., Dorn, H.-P., Brauers, T., and Cohen, R. C.: Organic nitrate and secondary organic aerosol yield from NO3 oxidation of $\beta$-pinene evaluated using a gas-phase kinetics/aerosol partitioning model, Atmos. Chem. Phys., 9, 14311449, doi:10.5194/acp-9-1431-2009, 2009.

Fry, J. L., Draper, D. C., Zarzana, K. J., Campuzano-Jost, P., Day, D. A., Jimenez, J. L., Brown, S. S., Cohen, R. C., Kaser, L., Hansel, A., Cappellin, L., Karl, T., Hodzic Roux, A., Turnipseed, A., Cantrell, C., Lefer, B. L., and Grossberg, N.: Observations ofgas- and aerosol-phase organic nitrates at BEACHON-RoMBAS2011, Atmos. Chem. Phys., 13, 85858605, doi:10.5194/acp-13-8585-2013, 2013.

Guo, Q., Hu, M., Guo, S., Wu, Z., Hu, W., Peng, J., Hu, W., Wu, Y., Yuan, B., Zhang, Q., and Song, Y.: The identification of source regions of black carbon at a receptor site off the eastern coast of China, Atmos. Environ., 100, 78-84, 2015.

Hayes, P. L., Ortega, A. M., Cubison, M. J., Froyd, K. D., Zhao, Y., Cliff, S. S., Hu, W. W., Toohey, D. W., Flynn, J. H., Lefer, B. L., Grossberg, N., Alvarez, S., Rappenglück, B., Taylor, J. W., Allan, J. D., Holloway, J. S., Gilman, J. B., Kuster, W. C., de Gouw, J. A., Massoli, P., Zhang, X., Liu, J., Weber, R. J., Corrigan, A. L., Russell, L. M., Isaacman, G., Worton, D. R., Kreisberg, N. M., Goldstein, A. H., Thalman, R., Waxman, E. M., Volkamer, R., Lin, Y. H., Surratt, J. D., Kleindienst, T. E., Offenberg, J. H., Dusanter, S., Griffith, S., Stevens, P. S., Brioude, J., Angevine, W. M., and Jimenez, J. L: Organic aerosol composition and sources in Pasadena, California, during the 2010 CalNex campaign, J. Geophys. Res.-Atmos., 118, 9233-9257, doi:10.1002/jgrd.50530, 2013.

He, L., Huang, X., Xue, L., Hu, M., Lin, Y., Zheng, J., Zhang, R., and Zhang, Y.: Submicron aerosol analysis and organic source apportionment in an urban atmosphere in Pearl River Delta of China using high-resolution aerosol mass spectrometry, J. Geo- 
phys. Res.-Atmos., 116, D12304, doi:10.1029/2010JD014566, 2011.

Heald, C. L., Kroll, J. H., Jimenez, J. L., Docherty, K. S., DeCarlo,P. F., Aiken, A. C., Chen, Q., Martin, S. T., Farmer, D. K., and Artaxo, P.: A simplified description of the evolution of organic aerosol composition in the atmosphere, Geophys. Res. Lett., 37, L08803, doi:10.1029/2010GL042737, 2010.

Hofzumahaus, A., Rohrer, F., Lu, K., Bohn, B., Brauers, T., Chang, C.C., Fuchs, H., Holland, F., Kita, K., Kondo, Y., Li, X., Lou, S., Shao, M., Zeng, L., Wahner, A., and Zhang, Y.: Amplified Trace Gas Removal in the Troposphere, Science, 324, 17021704, 2009.

Hu, W.-W., Hu, M., Yuan, B., Jimenez, J. L., Tang, Q., Peng, J.-F., Hu, W., Shao, M., Wang, M., Zeng, L. M., Wu, Y. S., Gong, Z. H., Huang, X. F., and He L. Y.: Insights on organic aerosol aging and the influence of coal combustion at a regional receptor site of central eastern China, Atmos. Chem. Phys., 13, 10095-10112, doi:10.5194/acpd-13-10809-2013, 2013.

Huang, R., Zhang, Y., Bozzetti, C., Ho, K., Cao, J., Han, Y., Daellenbach, K. R., Slowik, J. G., Platt, S.M., Canonaco, F., Zotter, P., Wolf, R., Pieber, S. M., Bruns, E. A., Crippa, M., Ciarelli, G., Piazzalunga, A., Schwikowski, M., Abbaszade, G., Schnelle-Kreis, J., Zimmermann, R., An, Z., Szidat, S., Baltensperger, U., Haddad, I. E., and Prévôt, A. S. H.: High secondary aerosol contribution to particulate pollution during haze events in china, Nature, 514, 218-222, 2014.

Huang, X.-F., Yu, J.-Z., He, L.-Y., and Yuan, Z.-B.: Water-soluble organic carbon and oxalate in aerosols at a coastal urban site in China: size distribution characteristics, sources and formation mechanisms, J. Geophys. Res.-Atmos., 111, D22212, doi:10.1029/2006JD007408, 2006.

Huang, X.-F., He, L.-Y., Hu, M., Canagaratna, M. R., Sun, Y., Zhang, Q., Zhu, T., Xue, L., Zeng, L.-W., Liu, X.-G., Zhang, Y.-H., Jayne, J. T., Ng, N. L., and Worsnop, D. R.: Highly timeresolved chemical characterization of atmospheric submicron particles during 2008 Beijing Olympic Games using an Aerodyne high-resolution aerosol mass spectrometer, Atmos. Chem. Phys., 10, 8933-8945, doi:10.5194/acp-10-8933-2010, 2010.

Huang, X.-F., He, L.-Y., Hu, M., Canagaratna, M. R., Kroll, J. H., Ng, N. L., Zhang, Y. H., Lin, Y., Xue, L., Sun, T.-L., Liu, X.G., Shao, M., Jayne, J. T., and Worsnop, D. R.: Characterization of submicron aerosols at a rural site in Pearl River Delta of China using an aerodyne high-resolution aerosol mass spectrometer. Atmos. Chem. Phys., 11, 1865-1877, doi:10.5194/acp-111865-2011, 2011.

Huang, X.-F., He, L.-Y., Xue, L., Sun, T.-L., Zeng, L.-W., Gong, Z.-H., Hu, M., and Zhu, T.: Highly time-resolved chemical characterization of atmospheric fine particles during 2010 Shanghai World Expo, Atmos. Chem. Phys., 12, 4897-4907, doi:10.5194/acp-12-4897-2012, 2012.

Huang, X.-F., Xue, L., Tian, X.-D., Shao, W.-W., Sun, T.-L.,Gong, Z.-H., Ju, W.-W., Jiang, B., Hu, M., and He, L.-Y.: Highly timeresolved carbonaceous aerosol characterization in Yangtze River Delta of China: composition, mixing state and secondary formation, Atmos. Environ., 64, 200-207, 2013.

Jayne, J. T., Leard, D. C., Zhang, X.-F., Davidovits, P., Smith,K. A., Kolb, C. E., and Worsnop, D. R.: Development of an aerosol mass spectrometer for size and composition analysis of submicron particles, Aerosol Sci. Tech., 33, 49-70, 2000.
Jimenez J. L., Jayne J. T., Shi Q., Kolb C. E., Worsnop D. R., Yourshaw I., Seinfeld J. H., Flagan R. C., Zhang X. F., Smith K. A., Morris J. W., and Davidovits P.: Ambient aerosol sampling using the aerodyne aerosol mass spectrometer, J. Geophys. Res.Atmos., 108, 7-8425, doi:10.1029/2001JD001213, 2003.

Jimenez, J. L., Canagaratna, M. R., Donahue, N. M., Prevot, A. S. H., Zhang, Q., Kroll, J. H., DeCarlo, P. F., Allan, J. D., Coe, H., Ng, N. L., Aiken, A. C., Docherty, K. S., Ulbrich, I. M., Grieshop, A. P., Robinson, A. L., Duplissy, J., Smith, J. D., Wilson, K. R., Lanz, V. A., Hueglin, C., Sun, Y. L., Tian, J., Laaksonen, A., Raatikainen, T., Rautiainen, J., Vaattovaara, P., Ehn, M., Kulmala, M., Tomlinson, J. M., Collins, D. R., Cubison, M. J., Dunlea, E. J., Huffman, J. A., Onasch, T. B., Alfarra, M. R., Williams, P. I., Bower, K., Kondo, Y., Schneider, J., Drewnick, F., Borrmann, S., Weimer, S., Demerjian, K., Salcedo, D., Cottrell, L., Griffin, R., Takami, A., Miyoshi, T., Hatakeyama, S., Shimono, A., Sun, J. Y., Zhang, Y. M., Dzepina, K., Kimmel, J. R., Sueper, D., Jayne, J. T., Herndon, S. C., Trimborn, A. M., Williams, L. R., Wood, E. C., Middlebrook, A. M., Kolb, C. E., Baltensperger, U., and Worsnop, D. R.: Evolution of Organic Aerosols in the Atmosphere, Science, 326, 1525-1529, 2009.

Kedia, S., Ramachandran, S., Rajesh, T. A., and Srivastava, R.: Aerosol absorption over Bay of Bengal during winter: variability and sources, Atmos. Environ., 54, 738-745, 2012.

Lan, Z.-J., Chen, D.-L., Li, X., Huang, X.-F., He, L.-Y., Deng, Y.G., Feng, N., and Hu, M.: Modal characteristics of carbonaceous aerosol size distribution in an urban atmosphere of South China, Atmos. Res., 100, 51-60, 2011.

Lanz, V. A., Alfarra, M. R., Baltensperger, U., Buchmann, B., Hueglin, C., and Prévôt, A. S. H.: Source apportionment of submicron organic aerosols at an urban site by factor analytical modelling of aerosol mass spectra, Atmos. Chem. Phys., 7, 15031522, doi:10.5194/acp-7-1503-2007, 2007.

Lee, B. P., Li, Y. J., Yu, J. Z., Louie, P. K. K., and Chan, C. K.: Physical and chemical characterization of ambient aerosol by hrtof-ams at a suburban site in hong kong during springtime 2011, J. Geophys. Res., 118, 8625-8639, 2013.

Lin, N., Tsay, S., Maring, H. B., Yen, M., Sheu, G., Wang, S., Chi, K.H., Chuang, M., Ou-Yang, C., Fu, J. S., Reid, J. S., Lee, C., Wang, L., Wang, J., Hsu, C. N., Sayer, A. M., Holben, B. N., Chu, Y., Nguyen, X. A., Sopajaree, K., Chen, S., Cheng, M., Tsuang, B., Tsai, C., Peng, C., Schnell, R. C., Conway, T., Chang, C., Lin, K., Tsai, Y. I., Lee, W., Chang, S., Liu, J., Chiang, W., Huang, S., Lin, T., and Liu, G.: An overview of regional experiments on biomass burning aerosols and related pollutants in Southeast Asia: From BASE-ASIA and the Dongsha Experiment to 7-SEAS, Atmos. Environ., 78, 1-9, 2013.

Matthew, B. M., Middlebrook, A. M., and Onasch, T. B.: Collection efficiencies in an Aerodyne Aerosol Mass Spectrometer as a function of particle phase for laboratory generated aerosols, Aerosol Sci. Tech., 42, 884-898, 2008.

Middlebrook, A. M., Bahreini, R., Jimenez, J. L., and Canagaratna, M. R.: Evaluation of Composition-Dependent Collection Efficiencies for the Aerodyne Aerosol Mass Spectrometer using Field Data, Aerosol Sci. Tech., 46, 258-271, 2012.

Ng, N. L., Canagaratna, M. R., Zhang, Q., Jimenez, J. L., Tian,J., Ulbrich, I. M., Kroll, J. H., Docherty, K. S., Chhabra, P.S., Bahreini, R., Murphy, S. M., Seinfeld, J. H., Hildebrandt, L., Donahue, N. M., DeCarlo, P. F., Lanz, V. A., Prévôt, A. S. 
H., Dinar, E., Rudich, Y., and Worsnop, D. R.: Organic aerosol components observed in Northern Hemispheric datasets from Aerosol Mass Spectrometry, Atmos. Chem. Phys., 10, 46254641, doi:10.5194/acp-10-4625-2010, 2010.

Ovadnevaite, J., O’Dowd, C., Dall'Osto, M., Ceburnis, D., Worsnop, D. R., and Berresheim, H.: Detecting high contributions of primary organic matter to marine aerosol: A case study, Geophys. Res. Lett., 38, L02807, doi:10.1029/2010g1046083, 2011.

Raatikainen, T., Vaattovaara, P., Tiitta, P., Miettinen, P., Rautiainen, J., Ehn, M., Kulmala, M., Laaksonen, A., and Worsnop, D. R.: Physicochemical Properties and Origin of Organic Groups Detected in Boreal Forest Using an Aerosol Mass Spectrometer, Atmos. Chem. Phys., 10, 2063-2077, doi:10.5194/acp-10-20632010, 2010.

Robinson, N. H., Hamilton, J. F., Allan, J. D., Langford, B., Oram, D. E., Chen, Q., Docherty, K., Farmer, D. K., Jimenez, J. L., Ward, M. W., Hewitt, C. N., Barley, M. H., Jenkin, M. E., Rickard, A. R., Martin, S. T., McFiggans, G., and Coe, H.: Evidence for a significant proportion of secondary organic aerosol from isoprene above a maritime tropical forest, Atmos. Chem. Phys., 11, 1039-1050, doi:10.5194/acp-11-1039-2011, 2011.

Rollins, A. W., Browne, E. C., Min, K.-E., Pusede, S. E., Wooldridge, P. J., Gentner, D. R., Goldstein, A. H., Liu, S., Day, D. A., Russell, L. M., and Cohen, R. C.: Evidence for $\mathrm{NO}_{X}$ Control over Nighttime SOA Formation, Science, 337, 1210-1212, 2012.

Sato, K., Takami, A., Isozaki, T., Hikida, T., Shimono, A., and Imamura, T.: Mass spectrometric study of secondary organic aerosol formed from the photo-oxidation of aromatic hydrocarbons, Atmos. Environ., 44, 1080-1087, 2010.

Smith, R. J.: Use and misuse of the reduced major axis for linefitting, Am. J. Phys. Anthropol., 140, 476-486, 2009.

Sun, J.-Y., Zhang, Q., Canagaratna, M. R., Zhang, Y. M., Ng, N. L., Sun, Y. L., Jayne, J. T., Zhang, X. C., Zhang, X. Y., and Worsnop, D. R.: Highly time- and size-resolved characterization of submicron aerosol particles in beijing using an aerodyne aerosol mass spectrometer, Atmos. Environ., 44, 131-140, 2010.

Sun, Y., Wang, Z., Dong, H., Yang, T., Li, J., Pan, X., Chen, P., and Jayne, J. T.: Characterization of summer organic and inorganic aerosols in beijing, china with an aerosol chemical speciation monitor, Atmos. Environ., 51, 250-259, doi:10.1016/j.atmosenv.2012.01.013, 2012.

Sun, Y.-L., Zhang, Q., Macdonald, A. M., Hayden K., Li, S. M., Liggio, J., Liu, P. S. K., Anlauf, K. G., Leaitch, W. R., Steffen, A., Cubison, M., Worsnop, D. R., van Donkelaar, A., and R. V. Martin.: Size-resolved aerosol chemistry on Whistler Mountain, Canada with a high-resolution aerosol mass spectrometer during INTEX-B, Atmos. Chem. Phys., 9, 3095-3111, doi:10.5194/acp9-3095-2009, 2009.

Sun, Y.-L., Wang, Z. F., Fu, P. Q., Yang, T., Jiang, Q., Dong, H. B., Li, J., and Jia, J. J.: Aerosol composition, sources and processes during wintertime in beijing, china, Atmos. Chem. Phys., 13, 4577-4592, doi:10.5194/acp-13-4577-2013, 2013.

Sun, Y.-L., Wang, Z.-F., Zhang, Q., Wang, Q.-Q., Fu, X.-L., Pan, X.-L., Jayne, J., and Worsnop, D. R.: Long-term real-time measurements of aerosol particle composition in Beijing, China: seasonal variations, meteorological effects, and source analy- sis, Atmos. Chem. Phys., 15, 10149-10165, doi:10.5194/acp-1510149-2015, 2015.

Takegawa, N., Miyakawa, T., Kuwata, M., Kondo, Y., Zhao, Y., Han, S., Kita, K., Miyazaki, Y., Deng, Z., Xiao, R., Hu, M., van Pinxteren, D., Herrmann, H., Hofzumahaus, A., Holland, F., Wahner, A., Blake, D. R., Sugimoto, N., and Zhu, T.: Variability of submicron aerosol observed at a rural site in Beijing in the summer of 2006, J. Geophys. Res., 114, D00G05, doi:10.1029/2008jd010857, 2009.

Ulbrich, I. M., Canagaratna, M. R., Zhang, Q., Worsnop, D. R., and Jimenez, J. L.: Interpretation of organic components from Positive Matrix Factorization of aerosol mass spectrometric data, Atmos. Chem. Phys., 9, 2891-2918, doi:10.5194/acp-9-2891-2009, 2009.

van Donkelaar, A., Martin, R. V., Brauer, M., Kahn, R., Levy, R., Verduzco, C., and Villeneuve, P. J.: Global estimates of ambient fine particulate matter concentrations from satellite-based aerosol optical depth: Development and application, Environ. Health Persp., 118, 847-855, 2010.

Wang, J., Onasch, T. B., Ge, X., Collier, S., Zhang, Q., Sun, Y., Yu, H., Chen, M., Prévôt, A. S. H., and Worsnop, D. R.: Observation of Fullerene Soot in Eastern China, Environ. Sci. Technol. Lett., 3, 121-126, 2016.

Wu, Z. J., Hu, M., Shao, K. S., and Slanina, J.: Acidic gases, NH3 and secondary in organic ions in PM10 during summertime in Beijing, China and their relation to air mass history, Chemosphere, 76, 1028-1035, 2009.

Xiao, R., Takegawa, N., Zheng, M., Kondo, Y., Miyazaki, Y., Miyakawa, T., Hu, M., Shao, M., Zeng, L., Gong, Y., Lu, K., Deng, Z., Zhao, Y., and Zhang, Y. H.: Characterization and source apportionment of submicron aerosol with aerosol mass spectrometer during the pride-prd 2006 campaign, Atmos. Chem. Phys., 11, 6911-6929, doi:10.5194/acp-11-6911-2011, 2011.

Xu, L., Guo, H., Boyd, C. M., Klein, M., Bougiatioti, A., Cerully,K. M., Hite, J. R., Isaacman-Van Wertz, G., Kreisberg, N. M., Knote, C., Olson, K., Koss, A., Goldstein, A. H., Hering, S.V., de Gouw, J., Baumann, K., Lee, S.-H., Nenes, A., Weber, R. J., and $\mathrm{Ng}$, N. L.: Effects of anthropogenic emissions on aerosol formation from isoprene and monoterpenes in the southeastern United States, P. Natl. Acad. Sci. USA, 112, 37-42, 2015a.

Xu, L., Suresh, S., Guo, H., Weber, R. J., and Ng, N. L.: Aerosol characterization over the southeastern United States using highresolution aerosol mass spectrometry: spatial and seasonal variation of aerosol composition and sources with a focus on organic nitrates, Atmos. Chem. Phys., 15, 7307-7336, doi:10.5194/acp15-7307-2015, 2015b.

Yang, F., Tan, J., Zhao, Q., Du, Z., He, K., Ma, Y., Duan, F., Chen, G., and Zhao, Q.: Characteristics of $\mathrm{PM}_{2.5}$ speciation in representative megacities and across China, Atmos. Chem. Phys., 11, 5207-5219, doi:10.5194/acp-11-5207-2011, 2011.

Zhang, Q., Alfarra, M. R., Worsnop, D. R., Allan, J. D., Coe, H., Canagaratna, M. R., and Jimenez, J. L.: Deconvolution and Quantification of Hydrocarbon-like and Oxygenated Organic Aerosols Based on Aerosol Mass Spectrometry, Environ. Sci. Technol., 39, 4938-4952, 2005.

Zhang, Q., Jimenez, J. L., Canagaratna, M. R., Ulbrich, I. M., Ng, N. L., Worsnop, D. R., and Sun, Y. L.: Understanding atmospheric organic aerosols via factor analysis of aerosol mass spectrometry: a review, Anal. Bioanal. Chem., 401, 3045-3067, 2011. 
Zhang, X., Hecobian, A., Zheng, M., Frank, N. H., and Weber, R.J.: Biomass burning impact on $\mathrm{PM}_{2.5}$ over the southeastern US during 2007: integrating chemically speciated FRM filter measurements, MODIS fire counts and PMF analysis, Atmos. Chem. Phys., 10, 6839-6853, doi:10.5194/acp-10-6839-2010, 2010.

Zhang, Y. L., J. Li, G. Zhang, P. Zotter, R. J. Huang, J. H. Tang, L. Wacker, A. S. H. Prevot, and S. Szidat :Radiocarbon-Based Source Apportionment of Carbonaceous Aerosols at a Regional Background Site on Hainan Island, South China, Environ. Sci. Technol., 48, 2651-2659, 2014.
Zhang, Y. M., Zhang, X. Y., Sun, J. Y., Lin,W. L., Gong, S. L., Shen, X. J., and Yang, S.: Characterization of new particle and secondary aerosol formation during summertime in beijing, china, Tellus B, 63, 382-394, 2011.

Zhu, L., Huang, X., Shi, H., Cai, X., and Song, Y.: Transport pathways and potential sources of PM10 in Beijing, Atmos. Environ., 45, 594-604, 2011. 